\title{
Connettere per conoscere e comunicare: sviluppi dell'applicazione UID 3.0
}

\author{
Cristian Farinella \\ Raissa Garozzo \\ Lorena Greco \\ Martino Pavignano \\ Jessica Romor
}

\section{Abstract}

Conoscenza, comunicazione e connessione sono le tre parole che hanno ispirato e guidato la creazione di una app dedicata alla comunità scientifica dell'Unione Italiana Disegno, tutt'ora in fase di implementazione.

II contributo racconta, in prima istanza, le fasi di ideazione e sviluppo dell'applicativo, avente l'obiettivo di amplificare gli attuali strumenti di comunicazione esistenti per ottimizzare la capacità di creare relazioni e connessioni fra informazioni e utenti.

Lo studio qui presentato intende proporsi poi, soprattutto, come un'occasione per riflettere sulla formulazione di un linguaggio grafico appropriato ed espressivo del settore scientifico disciplinare al quale si rivolge principalmente, fornendo una metodologia di rappresentazione utile per future applicazioni anche in ambiti diversi. Un linguaggio grafico che si articola in una variegata molteplicità di aspetti e peculiarità: dalla capacità di esprimere con efficacia e immediatezza informazioni di varia natura, raccogliere e rappresentare sinteticamente dati eterogenei e porli in immediata connessione tra loro, al collegamento diretto tra utenti di una rete diffusa, alla questione dei principi di inclusività, che si esplicano in primo luogo nell'attenzione riservata al tema affascinante dell'accessibilità visiva.

\section{Parole chiave}

app, networking, accessibilità, parole chiave, user interface.
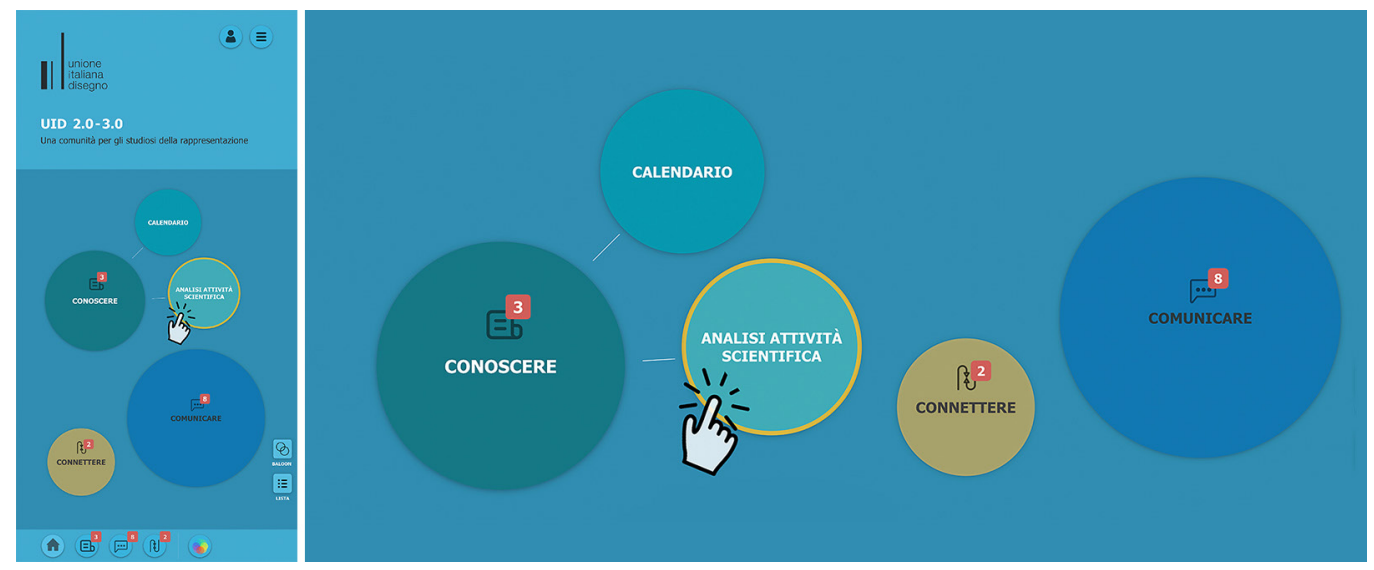


\section{Un'app per l'UID: dallo strumento al linguaggio}

L'Unione Italiana Disegno ha tra gli obiettivi principali, come recita l'articolo 2 del suo Statuto, lo sviluppo, la promozione e la coordinazione dell'attività di ricerca scientifica nell'ambito del Disegno, azioni attualmente affidate ai convegni - annuali, patrocinati e segnalati, che restituiscono una significativa immagine della produzione scientifica nel settore ICARI7 - e ad altri canali di comunicazione, sia ufficiali sia informali.

Partendo da questi canali attivi e dalla loro analisi e scomposizione, si è pensato a una applicazione che fosse in grado di mettere a sistema, potenziandone l'efficacia, i vari elementi individuati, con l'obiettivo di offrire alla comunità cui si rivolge uno strumento che soddisfi le esigenze di conoscenza e comunicazione dell'attività scientifica e che favorisca la connessione tra gli studiosi.

Questo primo obiettivo, posto ex ante, ha condotto in itinere all'opportunità di amplificare il valore scientifico del progetto attraverso lo studio e l'implementazione di un linguaggio grafico evoluto che fosse esso stesso espressione dei valori e dell'essenza del settore di appartenenza e che potesse quindi costituire un ulteriore momento di profonda riflessione sul Disegno nella sua accezione ampia di strumento di conoscenza, comunicazione e connessione. La prima fase operativa del progetto, come vedremo nel paragrafo successivo, ha riguardato la concezione e la struttura del prototipo di applicazione, declinato nelle sezioni di cui esso si compone, dedicate alla conoscenza delle attività - passate, presenti e future - dell'associazione, alle comunicazioni dei soci e all'opportunità di stabilire tra loro delle connessioni scientifiche. Successivamente, come vedremo, sono state sviluppate parallelamente le due fasi interconnesse di raccolta, selezione, archiviazione e analisi dei dati da una parte, e definizione del progetto grafico, dalla user experience, alla user interface, che comprende il wireframe, il mockup e il prototipo animato [I]. L'applicazione è tutt'ora in fase di concreto sviluppo e sarà disponibile sotto forma di progressive web app (fig. I).

Fig. I. Rappresentazione delle fasi di ideazione, progettazione e sviluppo dell'applicazione.

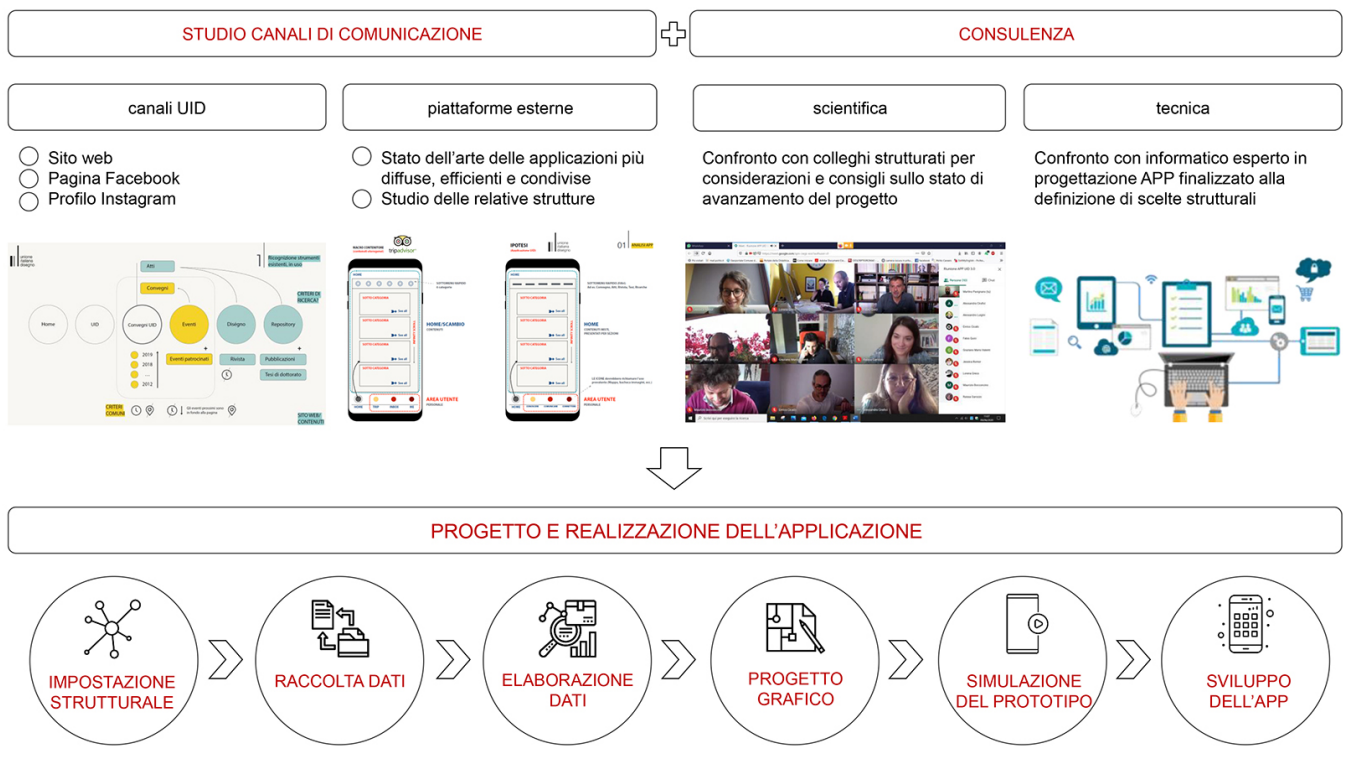

\section{La struttura dell'app}

La struttura del prototipo si compone di tre sezioni distinte ma interconnesse che, coerentemente agli obiettivi della proposta, rispecchiano le tre anime del progetto: le sezioni 'Conoscere', 'Comunicare' e 'Connettere' (fig. 2).

La sezione 'Conoscere' è un hub di informazioni relative alle iniziative promosse dall'UID. La sezione è suddivisa in due parti, rispettivamente dedicate alla raccolta della produzione scientifica in ambito UID, disponibile per l'utente in modo interattivo e personalizzabile, e il 


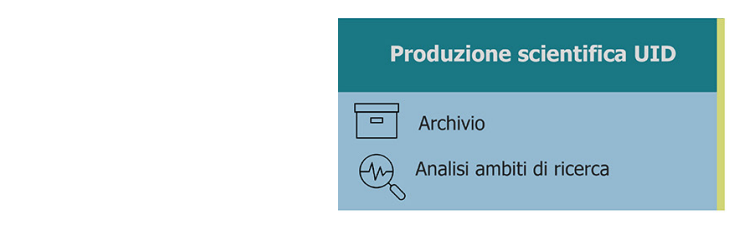

Fig. 2.Visualizzazione

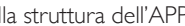
e sintesi delle funzioni contenute nelle sezioni 'Conoscere" "Comunicare' e 'Connettere'.
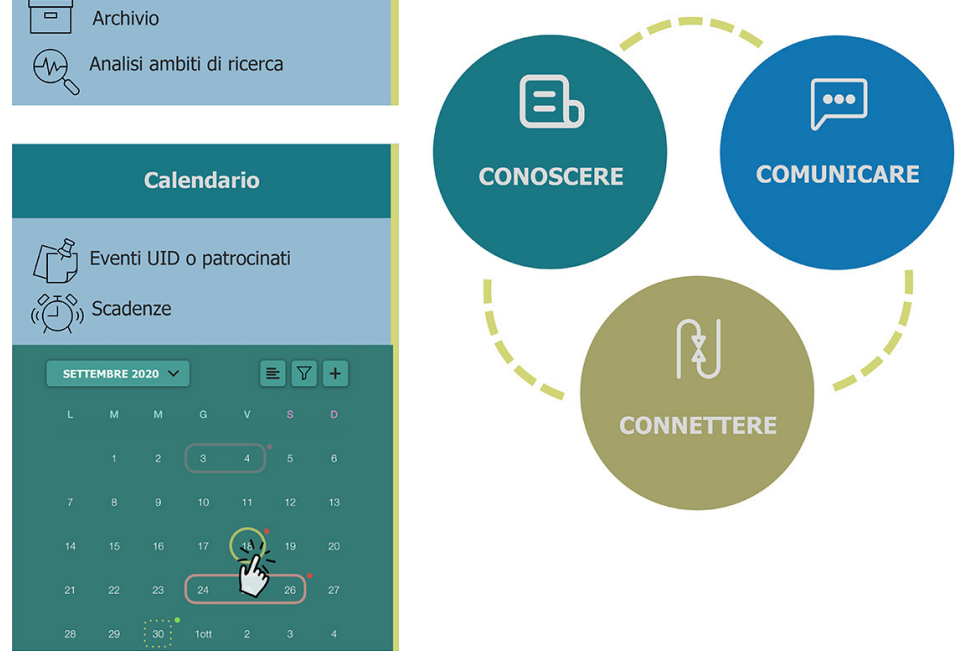

Bacheca riservata ai soci

Studi e indagini scientifiche 으름 Condivisione e confronto

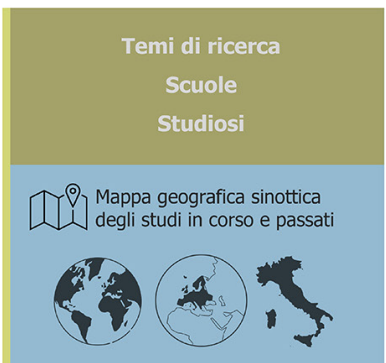

calendario, il cui obiettivo è informare circa gli eventi principali promossi dell'associazione. La rappresentazione delle informazioni relative agli eventi principali e la costituzione di un'agenda delle attività future fanno della sezione 'Conoscere' uno strumento funzionale per lo studioso, che può facilmente consultare i prodotti scientifici su una tematica di suo interesse, mediante una ricerca basata su parole chiave, e disporre di un calendario aggiornato sul quale visualizzare eventi e deadlines, siano esse riferite all'iscrizione a una conferenza o a una submission.

La sezione 'Comunicare' offre agli utenti un sistema di comunicazione mediante una bacheca nella quale i soci possono condividere interessi e ricerche scientifiche, attraverso il caricamento di immagini e brevi descrizioni testuali. La sezione, il cui scopo è la ricerca di sinergie e una sempre più proficua collaborazione tra studiosi, espleta una funzione divulgativa e di interazione tra ricercatori, mediante la possibilità di commentare i prodotti di ricerca pubblicati (fig. 3). La sezione, sviluppata nel prototipo, verrà concretizzata in una fase successiva del progetto.
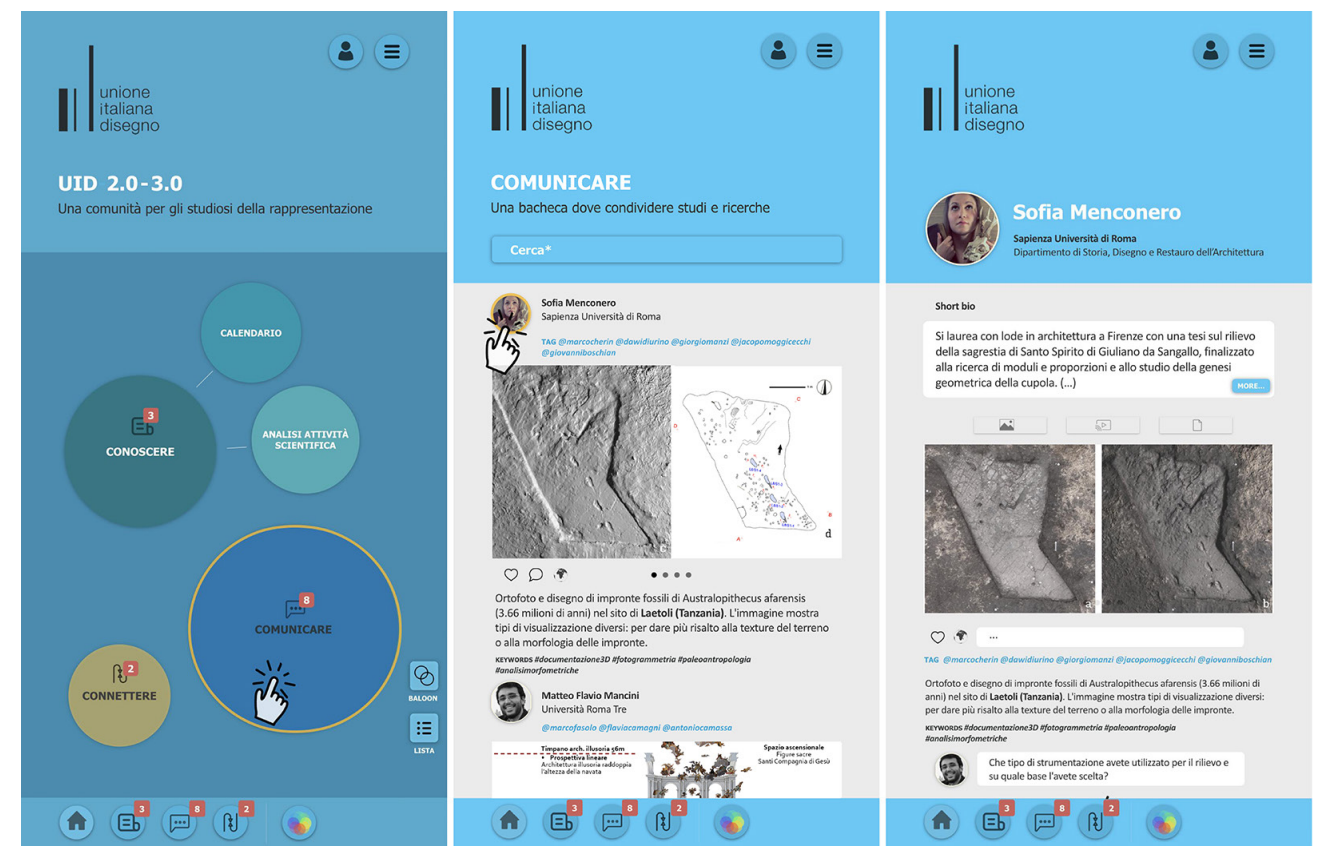
La sezione 'Connettere' intende evidenziare le relazioni tra studiosi, scuole, e interessi scientifici attraverso una mappa sinottica che permette di visualizzare l'affiliazione dello studioso, la localizzazione dei suoi oggetti di studio e le collaborazioni con altri ricercatori dell'UID. I dati per la mappa sinottica provengono dalle informazioni pubblicate sulla bacheca della sezione 'Comunicare' e dalla raccolta della produzione scientifica della sezione 'Connettere', arricchendosi mediante la pubblicazione di contenuti su questi due canali (fig. 4). In particolare, le connessioni tra studiosi derivano dalla compresenza di nomi e affiliazioni nelle sezioni.

Le tre anime dell'applicazione risultano così in continuo dialogo l'una con l'altra, soddisfacendo le esigenze di conoscenza, comunicazione e connessione attese.

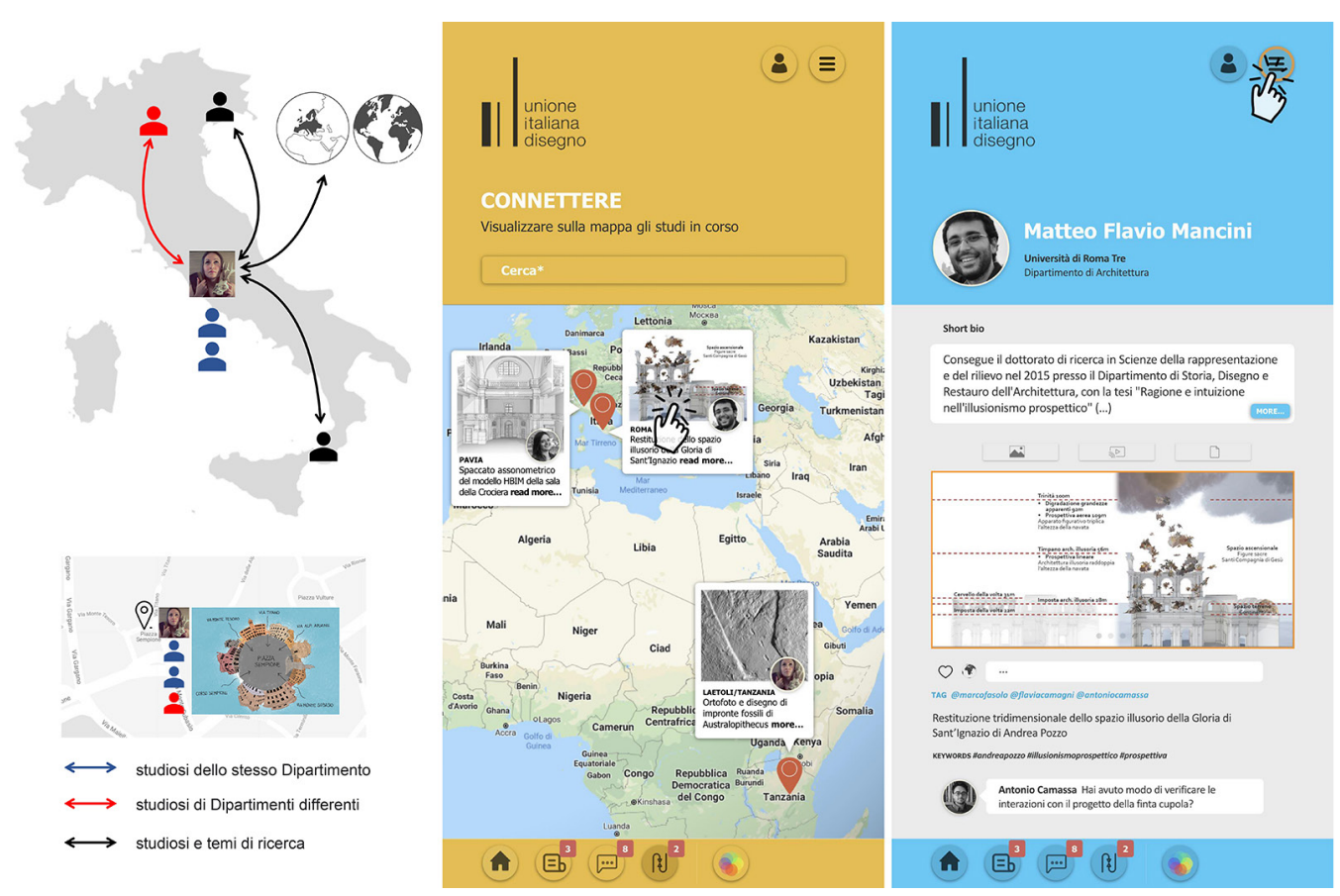

\section{II rilievo dei dati}

Per supportare le funzionalità delle tre sezioni, abbiamo individuato il nucleo di informazioni fondamentali, ovvero un insieme eterogeneo di dati digitali, su cui basare l'app. In tal senso, considerata la natura prototipale del progetto, per 'Conoscere' abbiamo ristretto la raccolta, implementabile nel tempo, agli Atti dei Convegni UID (da Firenze 2016 a Perugia 2019) e alla rivista diségno (dal 2017 al 2019). I dati delle pubblicazioni sono stati scelti in base a criteri noti e condivisi da studi ICARI7 [Luigini 2020] e di altri settori [Yang et al. 20 I 6]. Abbiamo scelto di estrapolare i dati in lingua inglese, per rendere il processo uniforme rispetto alla possibile provenienza estera dei soci e, contestualmente, ampliare il bacino di possibili utenti interessati. I dati raccolti sono: titolo, autore, abstract, parole chiave (fig. 5). Queste informazioni costituiscono una base dati composta da varie tabelle, tra loro connesse tramite i singoli ID di determinati record (contributo, collocazione, autore, ecc.). Una riflessione si è posta in merito all'utilizzo delle parole chiave, dal momento che una loro analisi potrebbe suggerire indirettamente l'interpretazione critica della struttura intellettuale [Shafique 20। 3, p. 63] delle ricerche del settore Icar 17. A tale scopo, è stato necessario sottoporle criticamente a un processo di normalizzazione ortografica e grafica, mantenendo la varietà delle forme utilizzate per esprimere concetti simili. In un secondo momento, per renderne più efficace la lettura, le abbiamo raggruppate in base ai concetti principali (parole-radice) che esse includono. A esemplificazione del processo proponiamo le parole chiave contenenti la 
Fig. 5. Visualizzazione delle pubblicazioni ufficiali UID prese a riferimento per la raccolta sistematica dei dati. Esempio della formattazione dei dati rilevati.

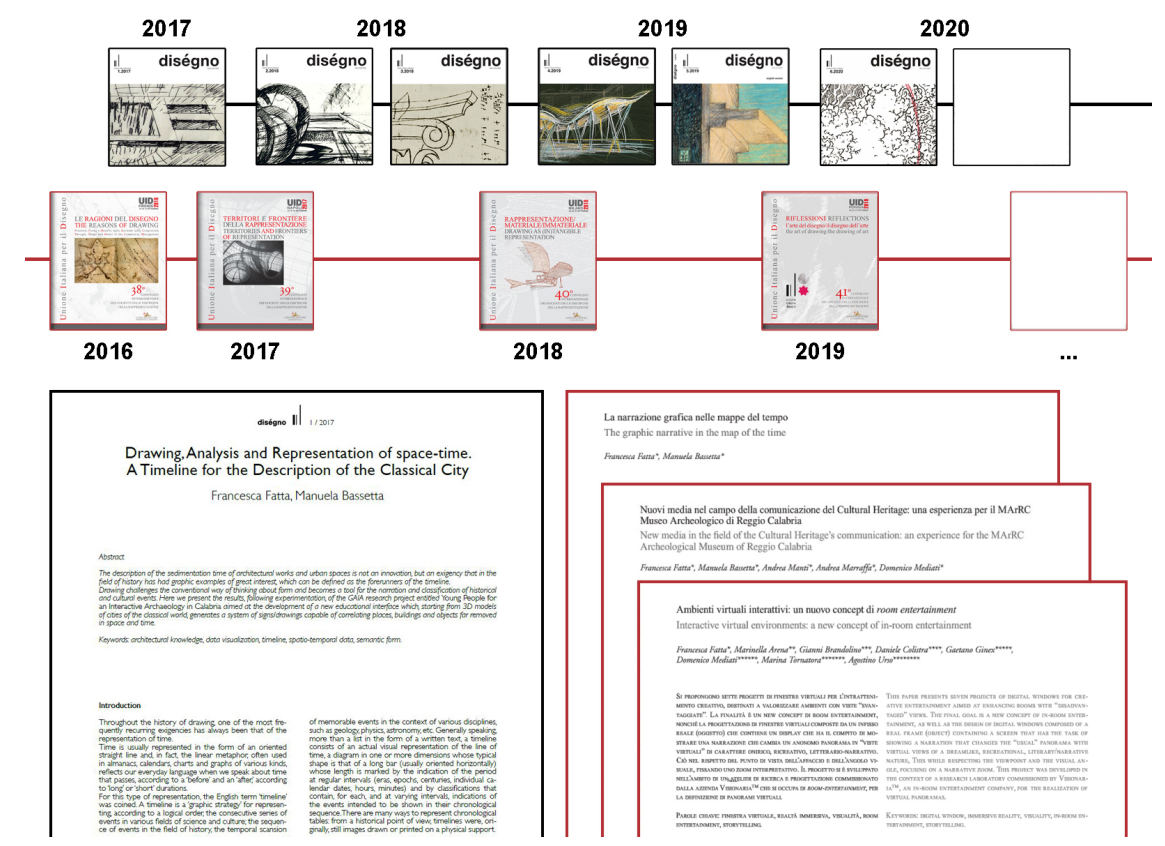

parola-radice heritage: esse sono state raggruppate, costituendo un insieme che si identifica con la singola parola, per poi declinarsi in numerose sfumature, come digital heritage, cultural heritage, historic-heritage BIM, ecc. (fig. 6). Per ogni parola chiave e, a livello superiore, parola-radice, l'app può quindi conteggiare le ricorrenze. Naturalmente, parole chiave composte da due o più termini sono state inserite in più gruppi, a seconda della rilevanza di ogni singolo termine in esse contenuto. In questo modo, l'app è in grado di proporre rappresentazioni riferite ai singoli anni, ovvero di comprarne i risultati anno per anno.

Per 'Comunicare', con un questionario online predisposto a tal fine, abbiamo chiesto ad alcuni colleghi che hanno partecipato al concorso UID 2.0-3.0 di fornire informazioni (immagini e didascalie, localizzazioni, tag dei colleghi con cui hanno collaborato, hashtag degli argomenti, commenti degli utenti) relative ai loro studi e ai loro interessi. Così, abbiamo simulato le attività relative alla creazione dei profili personali e alla bacheca, da noi ritenuta luogo primario di interazione e di scambio di idee nel contesto dell'app. Tutte queste informazioni confluiscono in 'Connettere', sezione volta a evidenziare le connessioni tra gli studiosi, le scuole e i rispettivi interessi scientifici, rappresentati su idoneo supporto cartografico da ele-

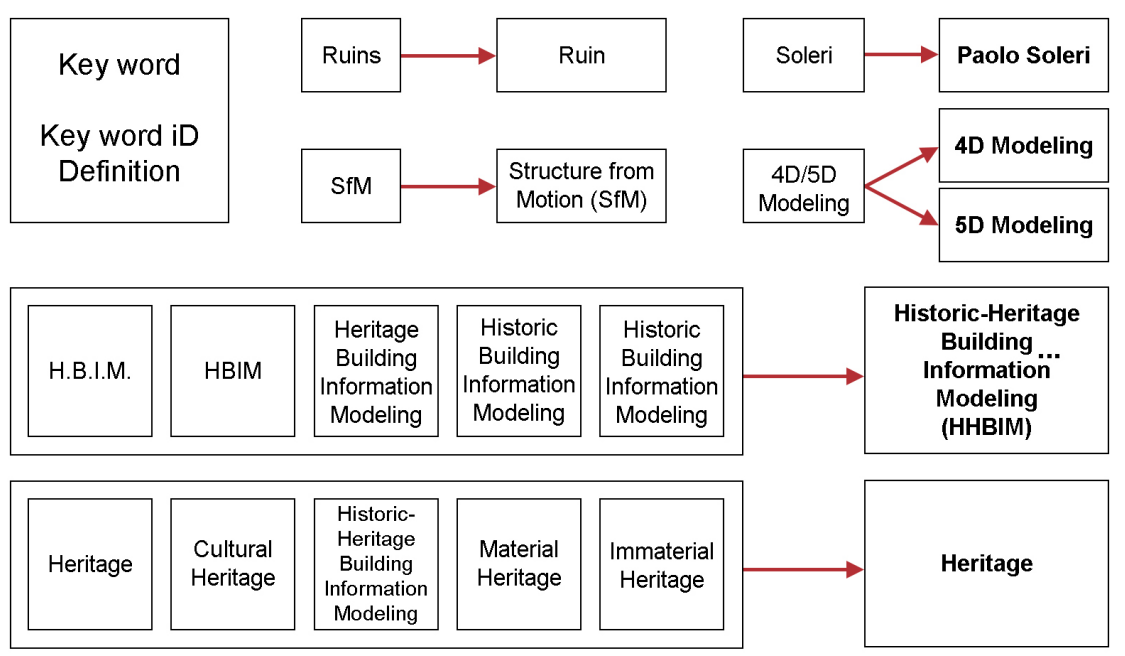

Fig. 6. Esempi di normalizzazione e accorpamento delle parole chiave. I termini declinati al plurale sono stati riportati al singolare. Gli acronimi sono stati slegati. I personaggi sono stati citati con nome e cognome. stati disambiguati sono parole chiave riferibili allo stesso concetto sono state normalizzate con la dicitura ritenuta più inclusiva. 
menti che ne individuano gli ambiti di interesse, per promuovere dialogo e collaborazione. I dati per la mappa provengono dalle informazioni pubblicate sulla bacheca in 'Comunicare' e dai profili, aggiornandosi con la pubblicazione di contenuti su questi due canali.

La mappa diventerà il luogo di visualizzazione per e dello studioso, collocato in base all'affiliazione dichiarata nella scheda utente. Allo stesso saranno collegati, ove indicati negli interventi in bacheca (tag e hashtag), gli oggetti di studio individuati tramite localizzazione geografica. È attualmente in fase di valutazione la possibilità di rappresentare anche le connessioni tra i vari studiosi, espresse dalla compresenza dei loro nomi in uno stesso post della bacheca o in articoli raccolti per la sezione 'Conoscere', nonché la distribuzione geografica delle parole chiave.

\section{Il progetto grafico}

Il progetto di una interfaccia grafica richiede una verifica costante sia della semplicità d'uso, tramite interaction design, che delle soluzioni visive e della user interface (UI) adottate, coinvolgendo molteplici discipline nel suo sviluppo. Gli imperativi dell'user experience (UX) sono riassumibili in poche proposizioni, come ben espresso dal noto designer e autore Steve Krug, che nel celebre libro Don't make me think! afferma: "Le persone spesso mi chiedono: qual è la cosa più importante che dovrei fare se voglio assicurarmi che il mio sito o la mia app sia facile da usare? La risposta è semplice. Niente di importante dovrebbe mai essere a più di due clic di distanza o non parlare la lingua dell'utente o essere coerente. Si tratta di... «Non farmi pensare!»»" [Krug 20 |4, p. 39] [2].

Le fasi riportate, da qui in avanti, presentano, in modo esplicativo e sintetico, alcune delle attività di ricerca e sviluppo condotte per dare seguito a una progettazione organica del nuovo applicativo UID.

\section{Analisi dell'esistente}

Lo sviluppo dell'app UID ha avuto inizio dall'analisi e dal riconoscimento delle aree e degli strumenti già in uso sul sito ufficiale dell'associazione. L'obiettivo è stato quello di non riproporre funzionalità esistenti ma di implementare e migliorare, ove possibile, la comunicazione degli eventi e delle attività fruibili da dispositivi mobili. Per procedere alla disamina, sono stati utilizzati i più comuni diagrammi di flusso utente (user flow), per comprendere la strutturazione del sito UID e il suo sviluppo interno (web-tree). L'aspetto dell'analisi (fig. 7) contiene già in nuce le prime proposte di progetto, molte delle quali rimaste inevase dall'attuale sviluppo in corso dell'app, e che potranno essere riprese in futuro dall'associazione. Tra queste, un sistema di premialità per gli utenti più attivi e virtuosi, così come la creazione di infografiche dinamiche e interattive per la consultazione dei dati raccolti dalla comunità scientifica.

\section{La scelta della Progressive Web App}

Le versioni Android e IOS di un applicativo mobile presentano numerose differenze nell'interfaccia e nell'interazione lato utente, rintracciabili tra le linee guida del design di entrambi i sistemi operativi. Per la natura sperimentale del progetto, e per prevedere una implementazione graduale, nel tempo, di altri moduli e funzioni aggiuntive, si è scelto di adottare una Progressive Web App (PWA). Si tratta di siti web programmabili nello standard html con i quali simulare, in maniera responsiva, il comportamento di un'app tramite il semplice accesso da browser. La soluzione consente di salvate sul desktop del dispositivo una versione mobile che simula in molti aspetti l'interazione che si avrebbe tramite app nativa, con il vantaggio di essere accessibile da ogni tipo di dispositivo e di essere più facilmente aggiornabile. 


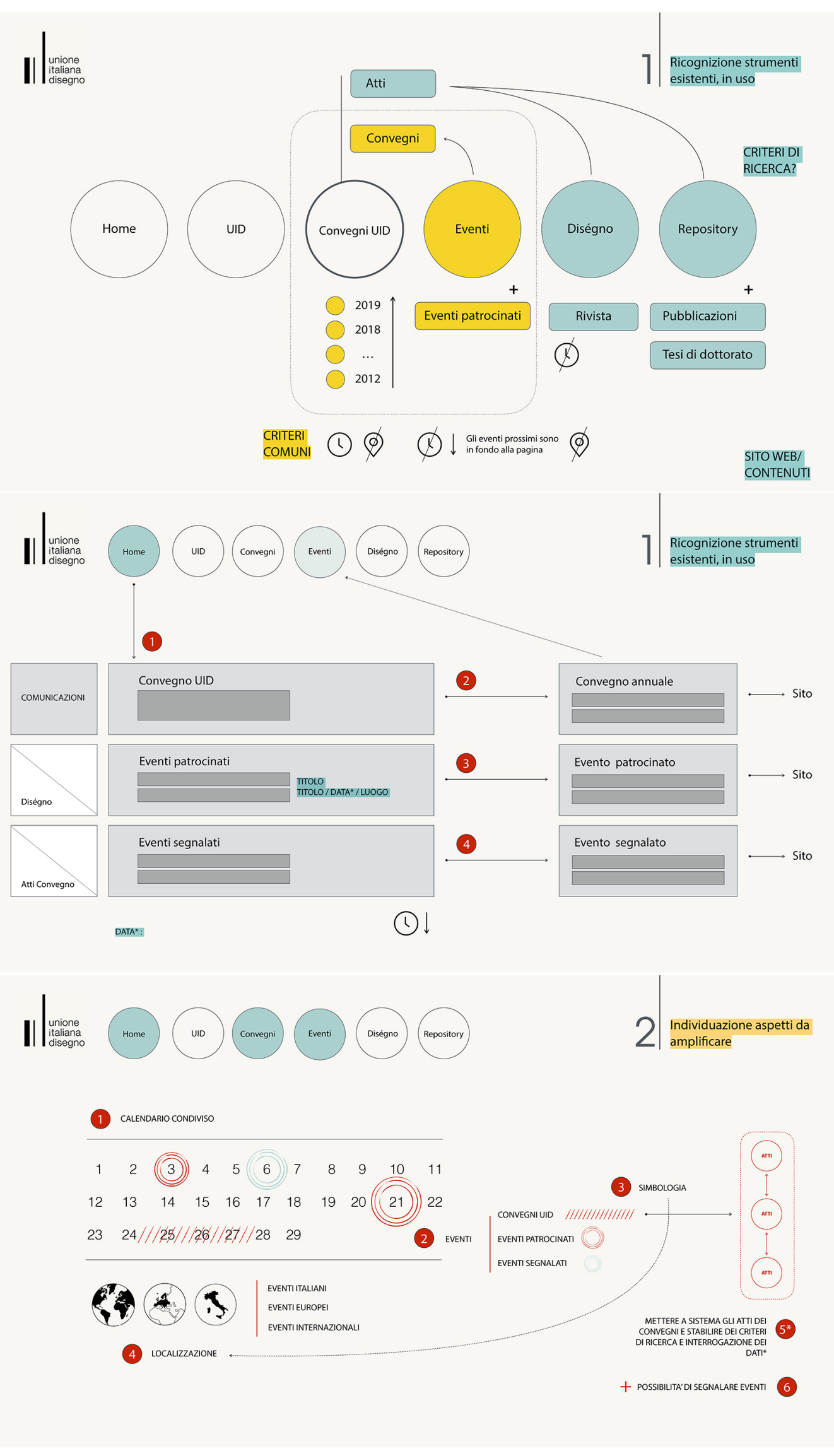


Fig. 8. Schema del colore triadico, impiegato per i

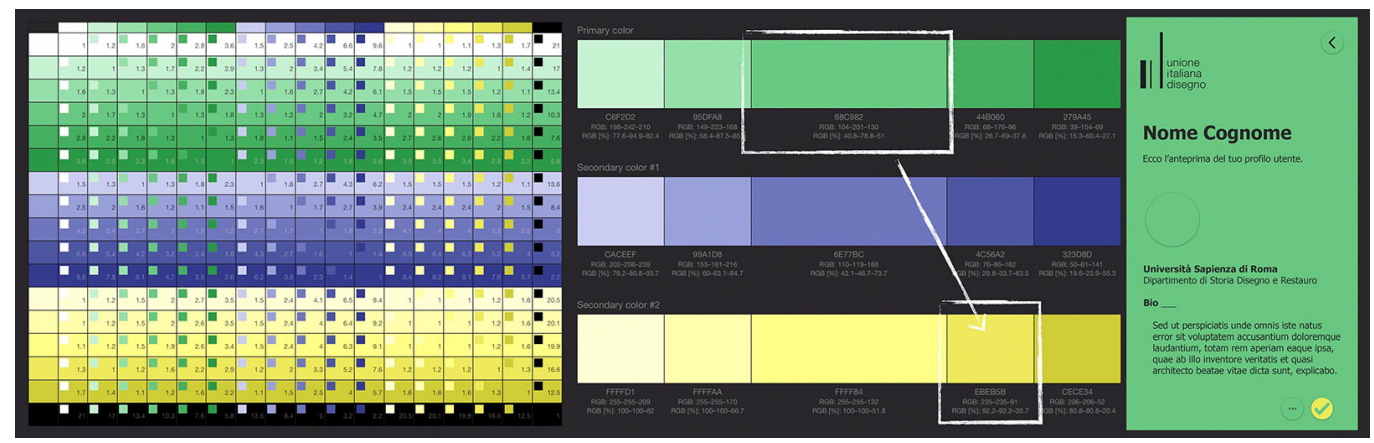

\section{Interfaccia utente e il ruolo del colore nell'accessibilità}

Nello sviluppo dello user interface dell'applicazione è stata prestata particolare attenzione al tema dell'accessibilità, sia nel rispetto delle direttive europee che nella personalizzazione del contenuto visivo e cromatico. Per quanto riguarda il rispetto delle normative [3], l'interfaccia grafica adottata consente a tutti gli utenti - compresi quelli affetti da forme di disabilità l'accesso alle informazioni [4]. L'aspetto che più caratterizza il linguaggio grafico, adottato nell'applicativo UID, riguarda l'utilizzo del colore. A partire dal progetto visivo iniziale, la tavolozza cromatica ha assunto un ruolo semantico per dare riconoscibilità alla mappa di navigazione. I tre ambiti del conoscere, del comunicare e del connettere, sono stati associati a tre colori differenti: verde acqua, blu e giallo. Inoltre, l'adozione di uno schema colore triadico, massimizzando il contrasto, ha permesso di accentrare l'attenzione su alcuni menu o link rilevanti nella lettura delle pagine (fig. 8), mentre gli schemi di colore analoghi (fig. 9) hanno generato variazioni della gradazione cromatica laddove viene indagato un tema specifico (come nel caso delle keywords). Se gli aspetti appena descritti sono di attualità nell'ambito del web design, l'app si propone, in aggiunta all'obiettivo di annullare le barriere visive, di informare gli utenti in merito alle differenti modalità di percezione del colore e consente di personalizzare l'interfaccia utente rispetto alle proprie esigenze. Dalla schermata di profilazione e creazione utente ( $\mathrm{fig}$. IOa), si può raggiungere la pagina di 'accessibilità' (fig. IOb), nella quale vengono indicate, tramite un menu a comparsa, le differenti modalità di percezione
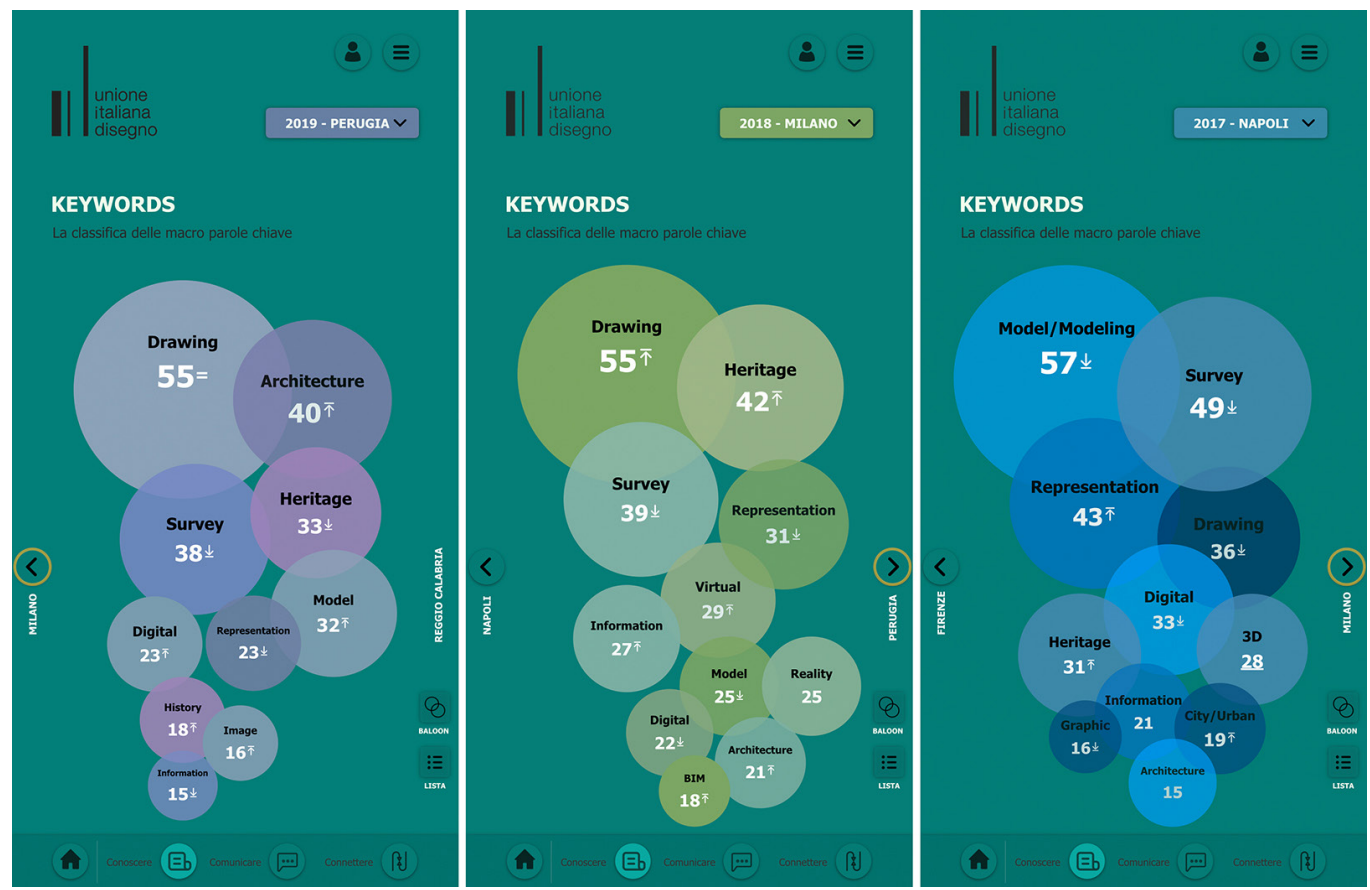
di approfondimento specifico, come nel caso delle keywords. Fig. 9. Gli schemi di
colore analoghi sono stati 
visiva (fig. 10c), confrontando la visione ordinaria con le più comuni forme di daltonismo, ovvero protanopia, deuteranopia, tritanopia e acromatopsia (fig. I0d). Scegliendo tra le modalità appena menzionate, l'app è in grado di variare e sostituire i colori di base in quelli che meglio aderiscono al range di tonalità percepibili dall'utente (fig. I I), permettendo una più efficace lettura dei contenuti. In conclusione, le configurazioni possibili dell'applicazione sono molteplici e pongono al centro un tema cruciale per chiunque si occupi di comunicazione visiva: la relatività del colore e la sua ampia gamma percettiva. Basti ricordare le prime pagine del noto Zur Farbenlehre (Teoria del colore) di Johann Wolfgang Goethe, dove il narratore e drammaturgo tedesco sosteneva che "i colori [...] appartengono del tutto o in gran parte al soggetto e all'occhio" [Goethe 20 I4, p. 2I], per specificare che esistono "colori fisiologici, poiché appartengono all'occhio sano e poiché li consideriamo come le necessarie condizioni del vedere [...] e colori patologici, che rendono possibile una più piena comprensione di quelli fisiologici, così come ogni condizione abnorme rende possibile la comprensione della condizione normale" [Goethe 20 I4, p. 2 I]. In conclusione, il proposito del progetto grafico d'interfaccia, oggetto di questa breve trattazione, è stato quello di tenere in considerazione il relativismo della percezione e, allo stesso tempo, di permettere una più concreta usabilità da parte degli utenti affetti da disturbi della visione.

Fig. I0. Schermata di profilazione e creazione utente (a). Nella pagin di 'accessibilità' (b) vengono indicate, tramite un menu a comparsa le differenti modalità $\mathrm{di}$ percezione visiva (c).

Confronto tra la version ordinaria e le più comuni forme di daltonismo, ovvero protanopia, deuteranopia, tritanopia e acromatopsia (d)
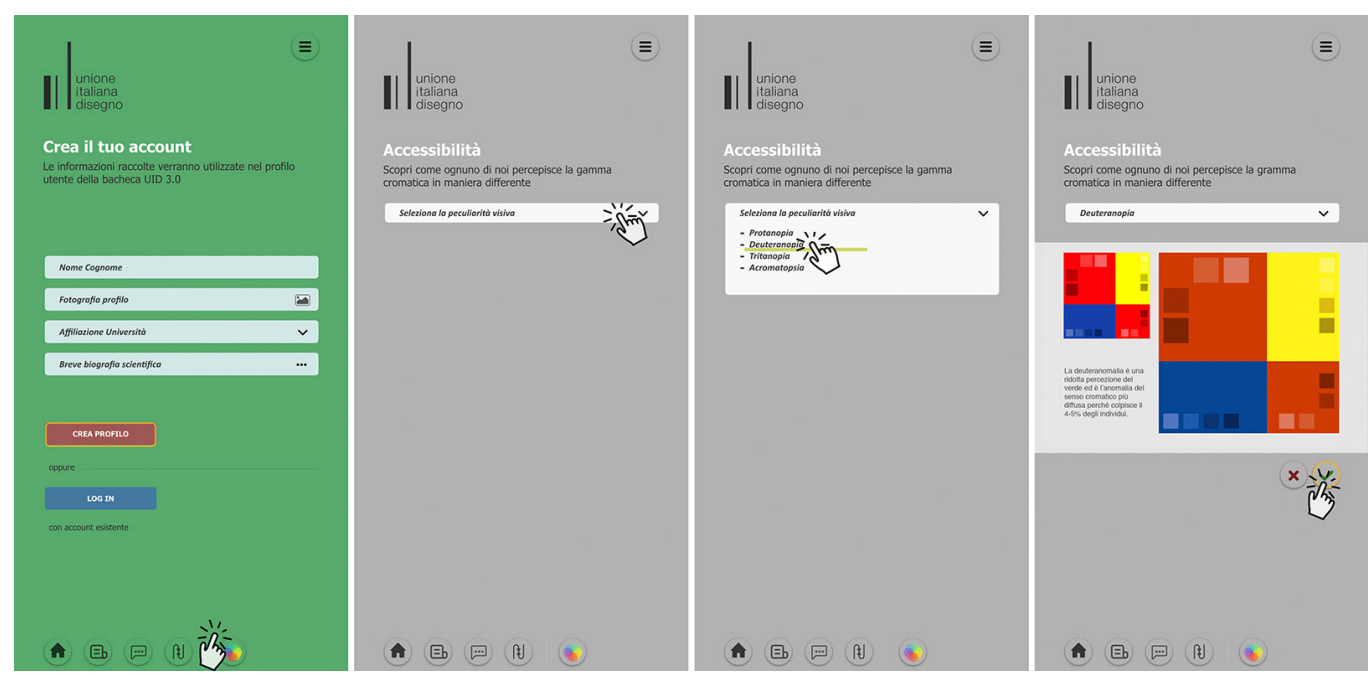

\section{Scenari di sviluppo}

Come abbiamo detto, sulla base del mockup e del prototipo animato realizzato e perfezionato in seguito al confronto con la comunità scientifica, si è avviato lo sviluppo concreto dell'APP, anche grazie al supporto informatico previsto dal progetto. L'effettiva risposta degli utenti alle funzioni per ora implementate dell'applicazione determinerà in futuro la possibilità di una espansione funzionale della stessa, in direzioni che si sono profilate ex post.Vi sono infatti alcuni aspetti che, pur non potendo essere sviluppati contestualmente poiché richiederebbero maggiori risorse temporali e sostanziali e competenze superiori, meritano una particolare attenzione in previsione di una futura evoluzione. Innanzitutto, la possibilità di innescare ulteriori riflessioni sui temi di ricerca emergenti, che si possono ravisare nell'andamento delle parole chiave di nuova acquisizione, e che molto avrebbero da dire sulle diverse ed eterogenee direzioni verso le quali il settore disciplinare evolve spontaneamente. Sarebbe poi, per lo stesso motivo, interessante tracciare le ricerche che gli utenti conducono navigando all'interno dell'applicazione, al fine di evidenziare gli interessi scientifici prevalenti e/o emergenti. Inoltre, altrettanto notevoli sarebbero l'analisi e lo sviluppo di sistemi di premialità in grado di incentivare l'impiego della futura applicazione, per amplificarne le potenzialità in termini di conoscenza, comunicazione, e connessione. 
Fig. I I. In relazione ai disturbi visivi, l'app è in grado di variare e sostituire i colori di base in quelli che meglio aderiscono al range di tonalità percepibit dall'utente.
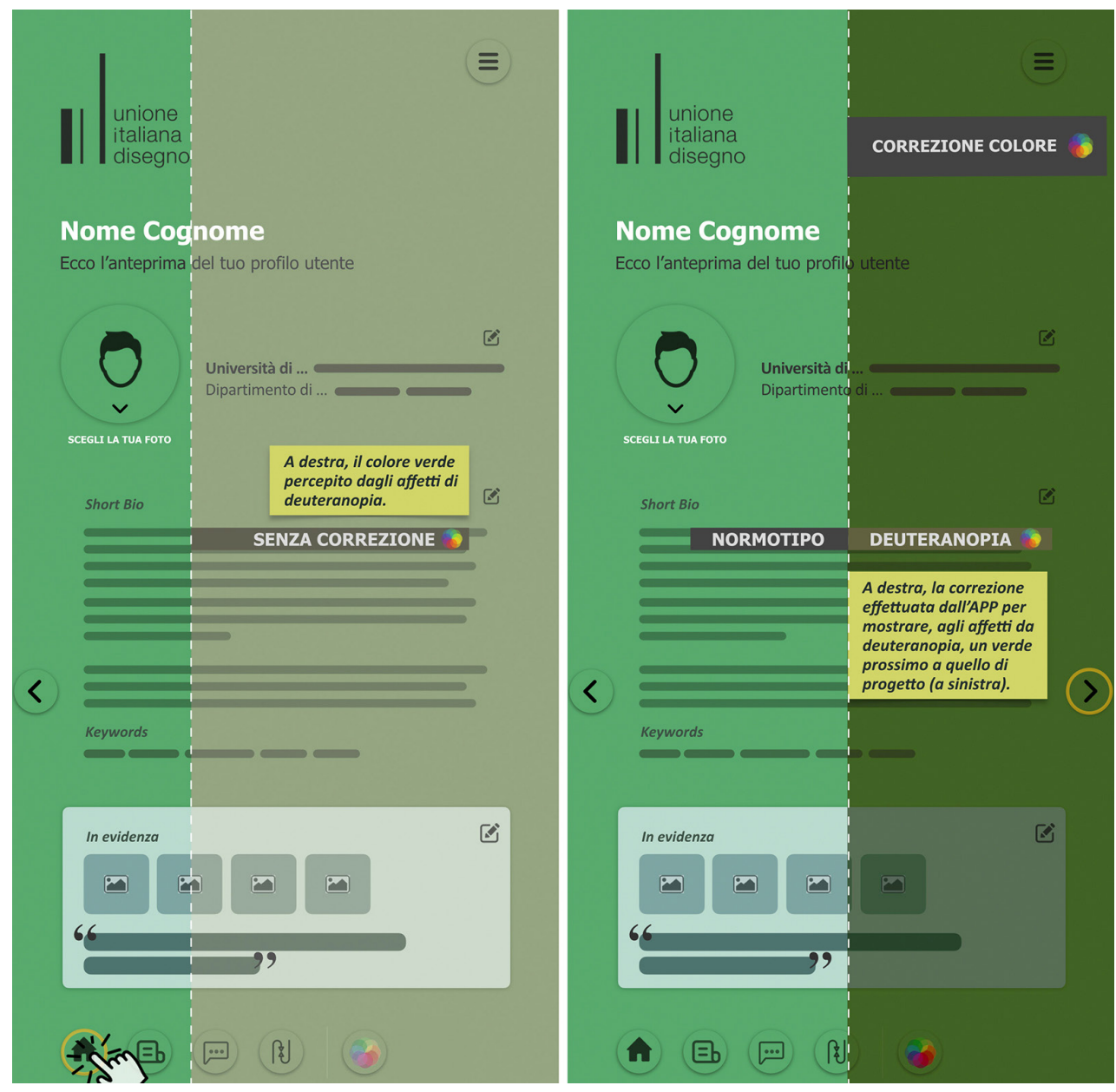

\section{Ringraziamenti}

Si ringrazia l'UID, e in particolare la Presidente prof.ssa Francesca Fatta, il prof. Giuseppe Amoruso e la commissione del concorso UID 2.0-3.0, per l'opportunità di realizzazione del progetto vincitore qui descritto. Si ringraziano i professori Salvatore Barba, Maurizio Bocconcino, Enrico Cicalò, Alessandra Cirafici, Alessandro Luigini, Fabio Quici, Graziano Mario Valenti per la consulenza scientifica e il dott. Paolo Burzacca per la consulenza informatica nelle fasi di progettazione e collaudo del prototipo. Si ringraziano i colleghi Sofia Menconero, Anna dell'Amico e Matteo Flavio Mancini per il supporto documentale nella simulazione dei profili utente del prototipo.

\section{Crediti}

Gli autori hanno lavorato nella piena condivisione del progetto in ogni sua fase. Raissa Garozzo, Martino Pavignano e Jessica Romor - alla quale è spettata la coordinazione scientifica - si sono occupati in particolare della raccolta, selezione, normalizzazione e analisi dei dati. Cristian Farinella e Lorena Greco si sono dedicati alla progettazione della User Interface, quindi wireframe, mockup e prototipo animato. Da un punto di vista strettamente redazionale, i paragrafi sono stati così ripartiti: I e 8 Jessica Romor, 2 Raissa Garozzo, 3 Martino Pavignano, 4-6 Cristian Farinella, 7 Lorena Greco.

\section{Note}

[I] L'animazione del prototipo dell'applicazione è raggiungibile all'indirizzo <https://bit.ly/2GhfA9o> (consultato il 25 maggio 2021).

[2] Steve Krug. Don't Make Me Think, Revisited: A Common Sense Approach to Web Usability. Apple Books, p. 39.

[3] Ci si riferisce in particolare al Decreto Legislativo del 10 Agosto 20 I 8, n. 106, consultabile al sito: https:/www.gazzettaufficiale.it/eli/id/20 I 8/09// I//8G00 /33/sg (consultato il 25 maggio 202 I). Si tratta del decreto di adeguamento alla normativa europea, in termini di accessibilità dei siti web e applicazioni mobili degli enti pubblici.

[4] Per fare alcuni esempi: le interazioni sui collegamenti attivi, tramite tocco delle dita, coinvolgono aree di ampie dimensioni, così da assicurare agli utenti con difficoltà motorie nell'uso delle mani di poter accedere senza difficoltà alle funzioni a schermo: i suoni impiegati enfatizzano le animazioni grafiche ma sono sempre supportati da menu di conferma fruibili tramite la vista, senza compromettere l'esperienza d'uso in presenza di disturbi dell'udito o sordità; infine, è stato evitato ogni tipo di effetto lampeggiante o di luce stroboscopica, per scongiurare l'eventuale incidenza di crisi epilettiche. 


\section{Riferimenti bibliografici}

Goethe J.W. (20|4). Teoria del colore. Milano: II Saggiatore.

Krug S. (20 I4). Don't Make Me Think, Revisited:A Common Sense Approach to Web Usability. Indianapolis (USA): New Riders (3 edizione).

Luigini A. (2020). Ricerca interdisciplinare e ICAR I7: una proposta per la definizione di un modello condiviso. In: Arena A. et al. (a cura di). Connettere: un disegno per annodare e tessere. Atti del $42^{\circ}$ Convegno Internazionale dei Docenti delle Discipline della Rappresentazione. Milano: Franco Angeli, pp. 567-575

Shafique M. (2013). Thinking inside the box? Intellectual structure of the knowledge base of innovation research (1988-2008). In Strategic Management Journal, 34(I), pp. 62-93.

Yang S. et al. (2016). Visualizing the intellectual structure of information science (2006-20I5): Introducing author keyword coupling analysis. In Journal of Informetrics, IO(I), pp. I32-150

\section{Autori}

Cristian Farinella, Sapienza Università di Roma, cristian.farinella@uniromal.it

Raissa Garozzo, Università degli Studi di Catania, raissa.garozzo@unict.it

Lorena Greco, Sapienza Università di Roma, lorena.greco@uniromal.it

Martino Pavignano, Politecnico di Torino, martino.pavignano@polito.it

Jessica Romor, Sapienza Università di Roma, jessica.romor@uniromal .it

Per citare questo capitolo: Farinella Cristian, Garozzo Raissa, Greco Lorena, Pavignano Martino, Romor Jessica (202 I). Connettere per conoscere e comunicare: sviluppi dell'applicazione UID 3.0/Connecting to know and communicate: development of the UID 3.0 application. In Arena A Arena M., Mediati D., Raffa P. (a cura di). Connettere. Un disegno per annodare e tessere. Linguaggi Distanze Tecnologie. Atti del $42^{\circ}$ Convegno Internazionale dei Docenti delle Discipline della Rappresentazione/Connecting. Drawing for weaving relationship. Languages Distances Technologies. Proceedings of the $42^{\text {th }}$ International Conference of Representation Disciplines Teachers. Milano: FrancoAngeli, pp. 700-721. 


\title{
Connecting to Know and Communicate: Development of the UID 3.0 Application
}

\author{
Cristian Farinella \\ Raissa Garozzo \\ Lorena Greco \\ Martino Pavignano \\ Jessica Romor
}

\begin{abstract}
Knowledge, communication and connection are the three words that inspired and guided the creation of an app dedicated to the scientific community of the Unione Italiana per il Disegno, which is still being implemented.

Firstly, the paper describes the phases of design and development of the application, which has the aim of amplifying the current existing communication tools to optimize the ability to create relationships and connections between information and users.

Subsequently, the study presented here wants primarily to be an opportunity to reflect on the formulation of an appropriate graphic language that is expressive of the scientific disciplinary sector to which it is mainly addressed, providing a representation methodology useful for future applications also in different fields. A graphic language that is divided into a variegated multiplicity of aspects and peculiarities, as: the ability to express effectively and immediately various kinds information, collect and synthetically represent heterogeneous data and place them in immediate connection with each other; the direct connection between users of a widespread network; the question of the principles of inclusiveness, which are expressed primarily in the attention paid to the fascinating theme of visual accessibility.
\end{abstract}

Keywords

app, networking, accessibility, keywords, user interface.
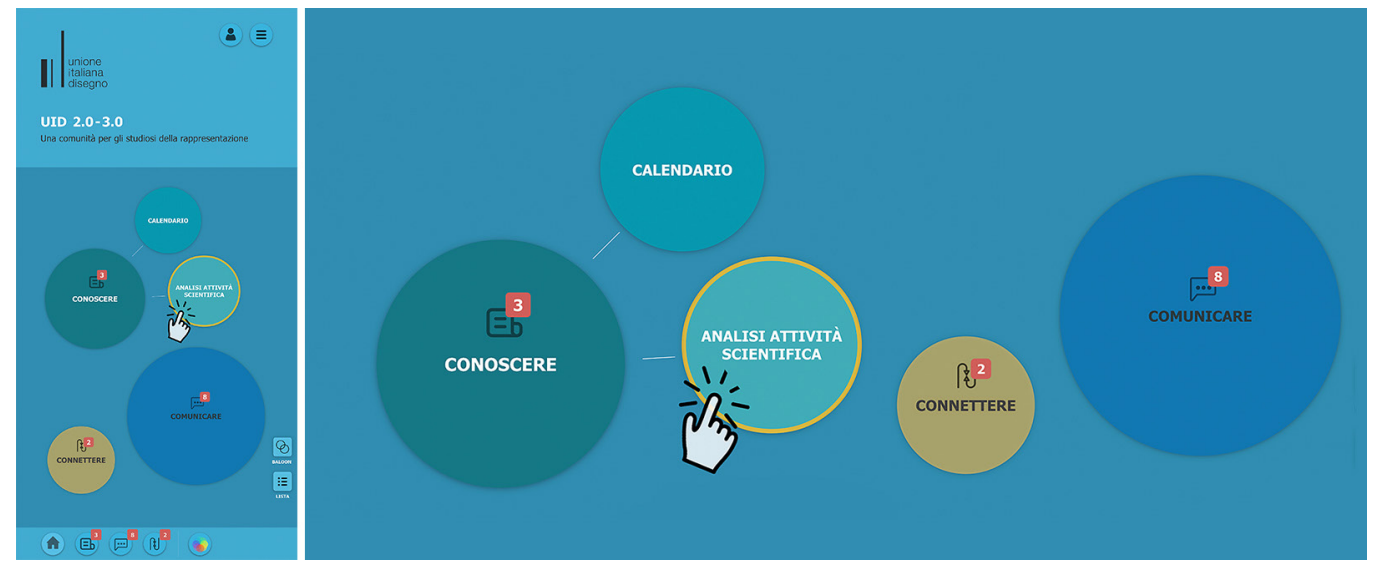


\section{An app for the UID: from tool to language}

The UID Unione Italiana per il Disegno scientific society has among its main objectives, as stated in article 2 of its Statute, the development, promotion and coordination of scientific research activity in the field of Drawing, actions currently entrusted to conferences -annual, sponsored and reported, which restore a significant image of scientific production in the ICARI7 sector- and to other communication channels, both official and informal.

Starting from the analysis of these active channels, we thought of an application that was able to systematize the various elements identified, enhancing their effectiveness, with the aim of offering to the community a tool that satisfies the needs of knowledge and communication of scientific activity and that favours the connection between scholars.

This first objective, set ex ante, led in itinere to the opportunity to amplify the scientific value of the project through the study and implementation of an evolved graphic language that was itself an expression of the values and essence of the sector to which it belongs and which could therefore constitute a further moment of profound reflection on Drawing in its broad meaning as an instrument of knowledge, communication and connection.

The first operational phase of the project, as we will see in the next paragraph, concerned the conception and structure of the application prototype, declined in the sections of which it is composed, dedicated to the knowledge of past, present and future activities of the association, the communication between members and the opportunity to establish scientific connections between them. Subsequently, as we will see, we developed in parallel two interconnected phases. On the one hand, the collection, selection, storage and analysis of the data; on the other one, the definition of the graphic project, from user experience to user interface, which includes wireframe, mockup and animated prototype [I]. The application is still undergoing concrete development and will be available as a progressive web app (fig. I).

Fig. I. Representing the app's steps of brainstorming, design and development.

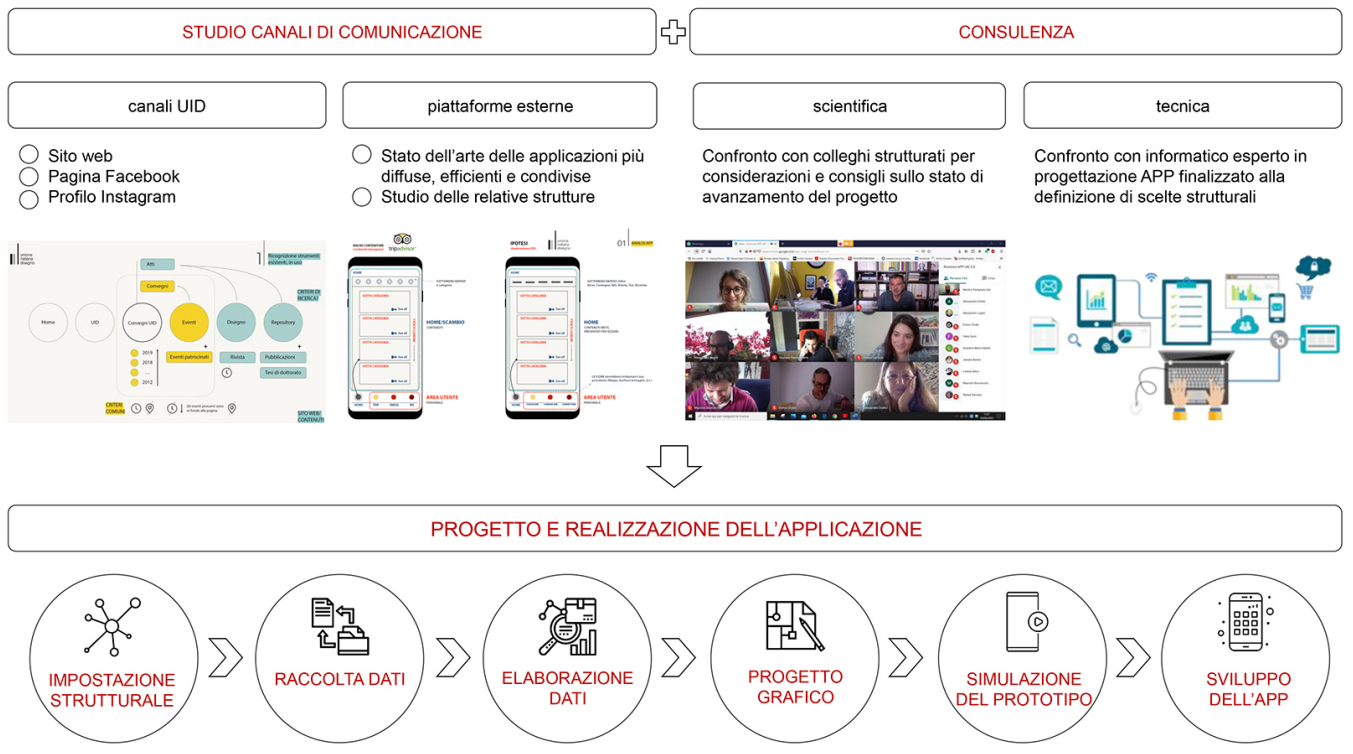

The structure of the app

The structure of the prototype consists of three separate but interconnected sections which, in line with the objectives of the proposal, reflect the three souls of the project: the "Know", "Communicate" and "Connect" sections (fig. 2). The "Know" section is an information hub concerning the initiatives promoted by UID. The section is split in two parts, respectively dedicated to the collection of the scientific publications of UID, available in an interactive and customizable way, and the calendar, aimed at informing about the main events 


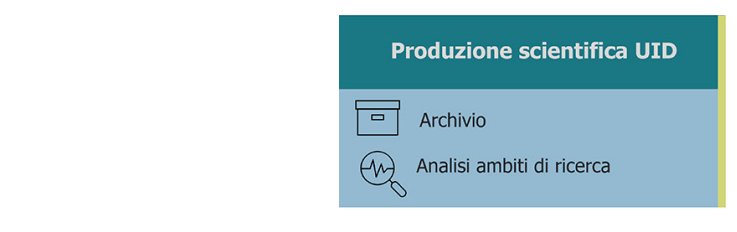

Fig. 2. Visualizing the structure of the app and the main functions related to sections "Know", "Communicate" and "Connect".

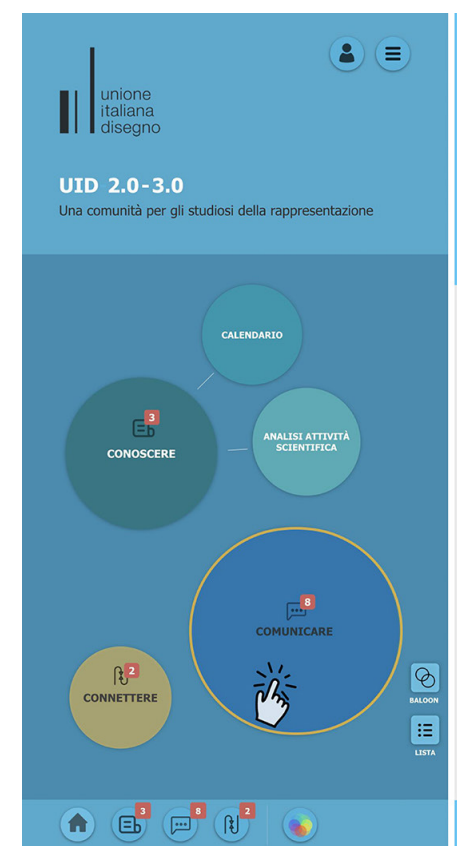

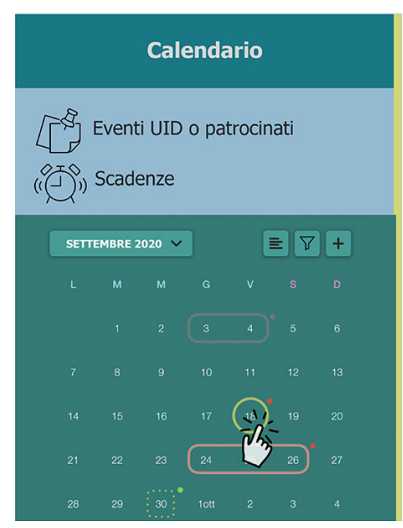

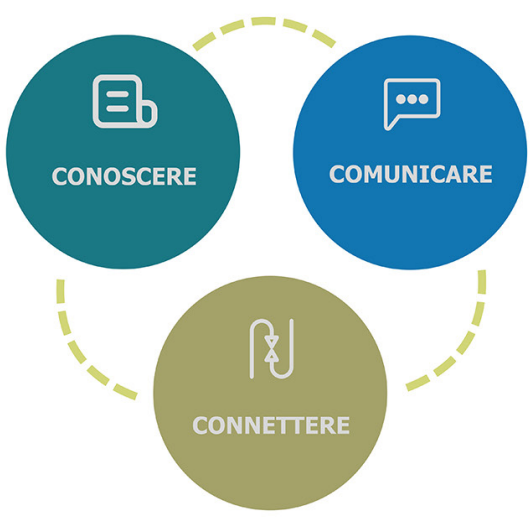

Bacheca riservata ai soci

Studi e indagini scientifiche 으름 Condivisione e confronto

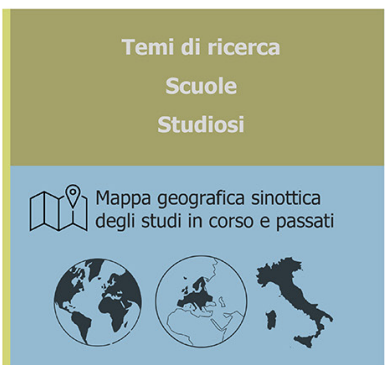

promoted by the association. The representation of main event details and the development of an agenda for future activities make the "Know" section a functional tool for scholars, who can easily consult scientific products on a topic of their interest; this is done by means of a keyword search, and the establishment of an up-to-date calendar where events and deadlines can be displayed, either for conference registration or submission. The "Communicate" section offers users a communication system through a notice board where members can share their interests and scientific research by uploading images and short text descriptions. This section, aimed at creating synergies and increasingly successful collaboration between scholars, serves the purpose of dissemination and interaction through the possibility of commenting on published research products (fig. 3). The section, developed in the prototype, will be realised in a further phase of the project. The "Connect" section aims at highlighting the interactions between scholars, schools, and scientific interests through a synoptic map that allows to visualize the scholars affiliation, the location of their objects of study and the collaborations with other UID researchers. The data for the synoptic map
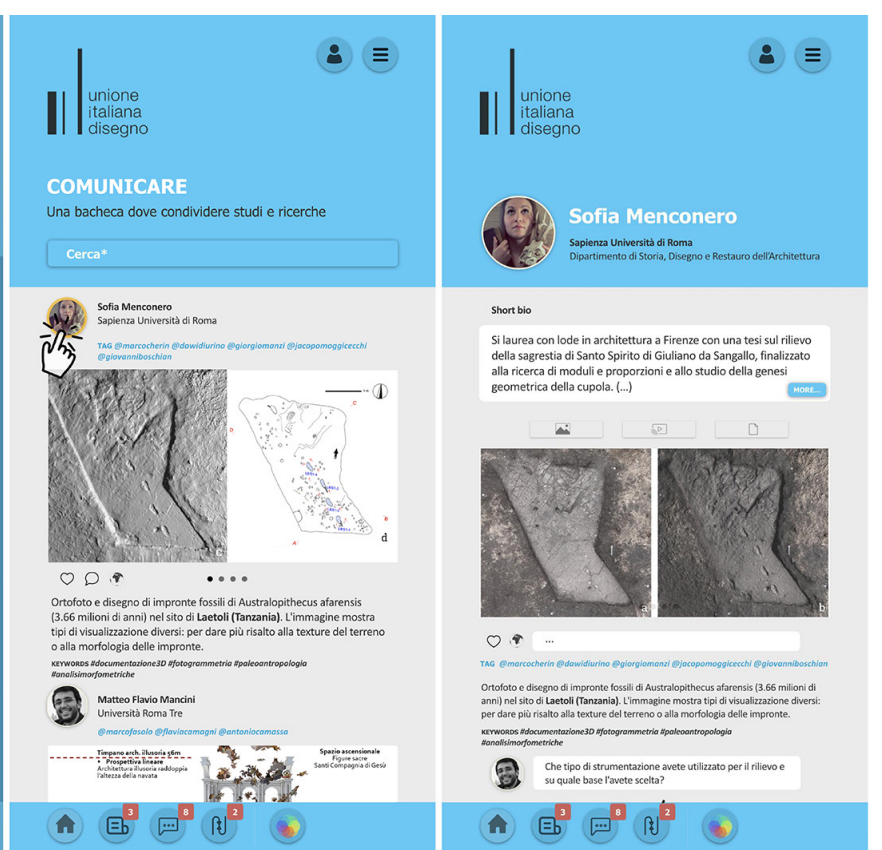
come from the information published on the notice board of the "Communicate" section and from the collection of scientific publications in the "Connect" section, enriched by the content published on these two channels (fig. 4). In particular, connections between scholars result from the co-presence of names and affiliations in the sections. The three cores of the application are thus in continuous communication with each other, fulfilling the expected needs for knowledge, communication and connection.

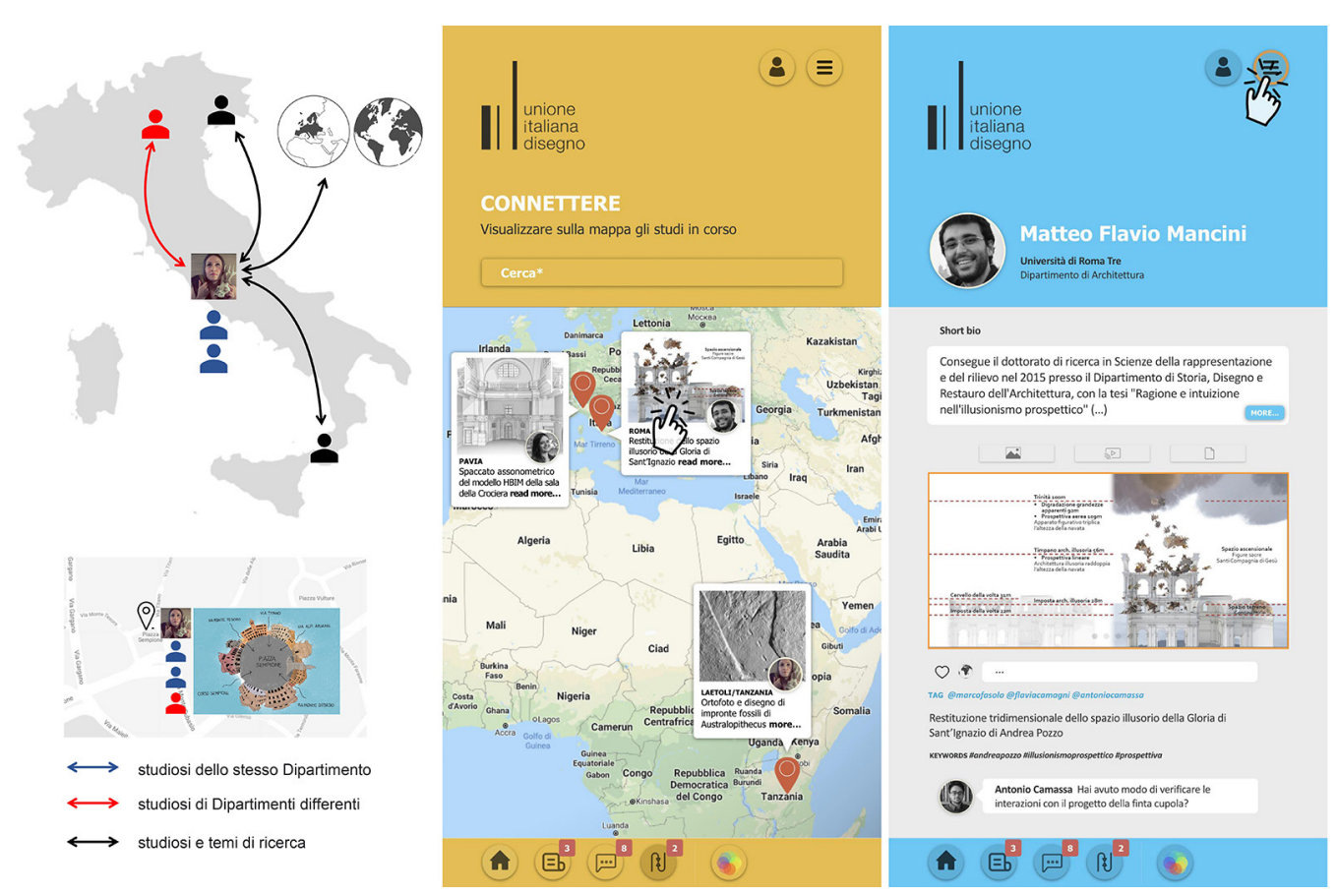

\section{Data survey}

Our app relies on a wide amount of data to execute functionalities related to all three sections, thus we had to define the core of fundamental information -or better a heterogeneous set of digital data- to 'feed' the app. While considering its prototype stage, for the section "Know" we evaluated to collect data from the Proceedings of the UID Conferences (from Florence 2016 to Perugia 2019) and from the diségno scientific journal (from 2017 to 2019$)$. This first set can be easily implemented in future. Data were selected on the basis of shared criteria by other scientific studies of our SSD ICAR/I7 [Luigini 2020] and of other SSD [Yang et al. 2016]. We chose to extrapolate data in English, to embrace all the contributions, even with respect to the possible foreign origin of UID associates and, at the same time, broaden the pool of possible interested users. Retrieved data are: title, author, abstract, keywords (fig. 5). This information feeds a database made of various tables, connected to each other through the individual IDs of certain records (contribution, location, author etc.). Now, a thought regarding a possible use of keywords arises: their analysis could indirectly suggest a critical interpretation of the intellectual structure [Shafique 20 I3, p. 63] of ICAR/ 17 related researches. Firstly, keywords must undergo a critical process of spelling and graphics normalization, both to define a more structured database and to retain the variety of forms used to express similar concepts. Then, we grouped them according to their main meanings (root-word) they include, to make their reading more effective. As an 
Fig. 5. Data extraction from scientific works published in official UID sources. Sample of data systematization.
Fig. 6. Examples of keywords normalization and grouping. Words written in the plural form have been reported in the singular one. Acronyms have been untied. Persons in general were mentioned with their first and last names. Ambiguous terms have been disambiguated We normalized beyuted rerable to the same referable to the same wording we deemed more inclusive.
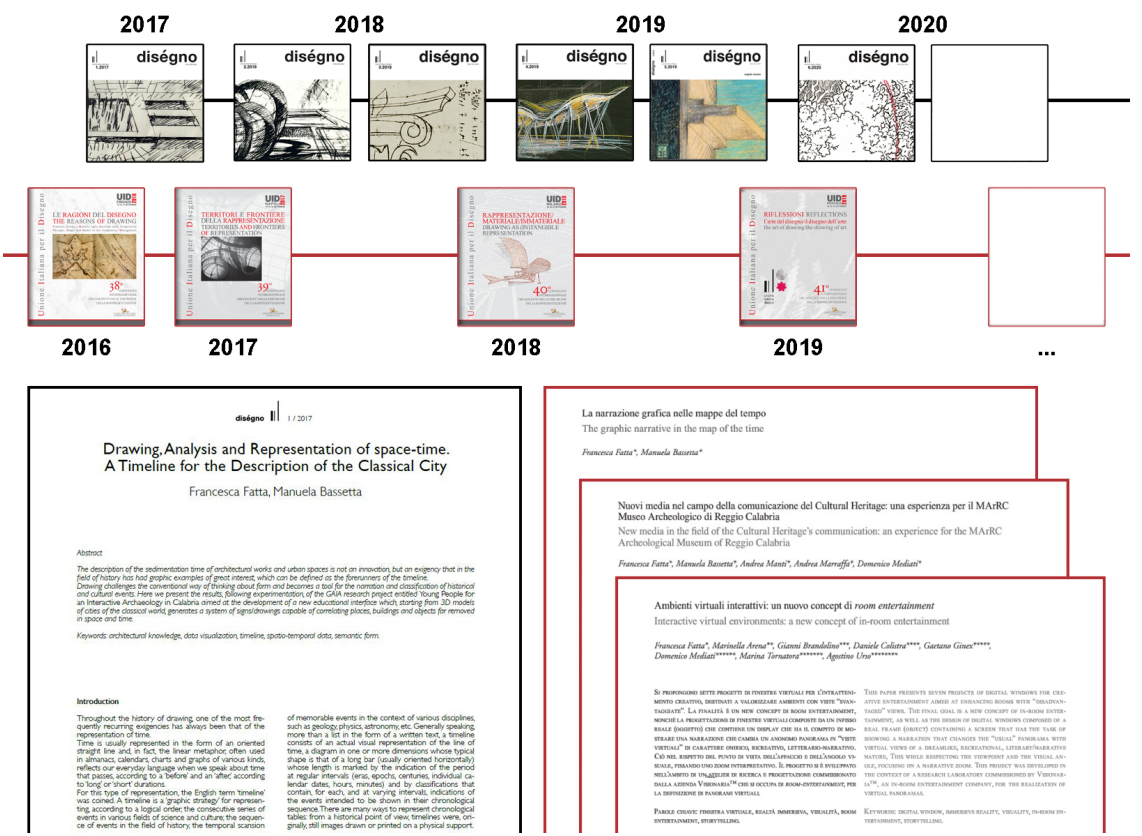

example, keywords containing the root-word heritage have been grouped together, thus creating a set which identifies itself with the single root-word, and can then be declined in numerous shades, such as digital heritage, cultural heritage, historic-heritage BIM, etc. (fig. 6). The app can then count the occurrences for each keyword and, at a higher level, for each root-word. Nonetheless, keywords formed by two or more words have been grouped into more sets. In this way, the app can highlight representations referring to individual years, or to compare results year by year.

To feed the section "Communicate", we submitted with an online questionnaire to some young colleagues who participated in the UID 2.0-3.0 competition, asking them to provide information (images and captions, localizations, tags of colleagues with whom they collaborated, hashtags of the topics, user comments) related to their studies and scientific interests. We then simulated the creation of users' personal profiles and notice board, which we consider the primary place of interaction and exchange of ideas in the context of the app. To promote dialogue and collaboration, all this information will converge in the "Connect" section, which is aimed at highlighting the connections between scholars, schools and their

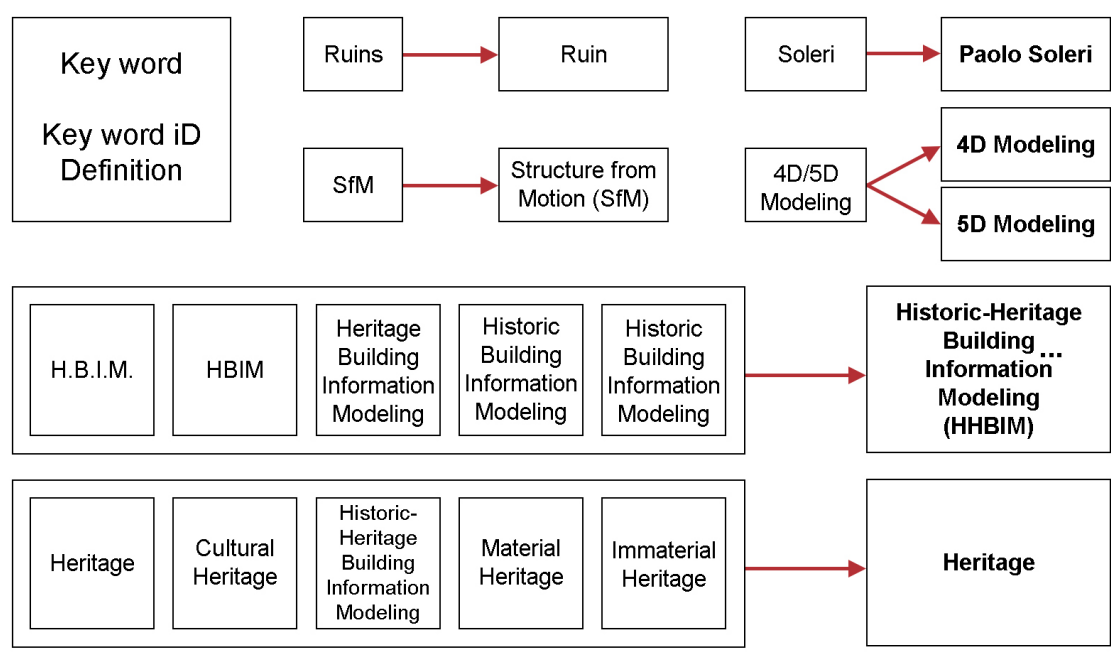


scientific interests, represented on suitable maps by graphic elements that identify the areas of interest. Data for the map comes directly from the information published on the Notice Board in "Communicate" and from users' profiles. Such data will be updated with the publication of contents on these two channels.

Scholars will be represented on the map on the basis of the declared affiliation and the map will provide them a tool to visually analyse and been analysed. The same map will link research topics and discussions published on the bulletin board (via tag and hashtag), thus providing them with a geolocation. Moreover, we are still evaluating the possibility of representing the connections between scholars, expressed by the coexistence of their names in the same post on the bulletin board or in articles collected for the "Know" section, as well as the geographical distribution of the Keywords.

\section{The graphic project}

A graphical interface project requires constant verification and ease of use through interaction design. The visual solutions and the user interface $(\mathrm{UI})$ adopted involve multiple disciplines in its development. The imperatives of the User Experience $(U X)$ can be summarized in a few propositions and expressed by the well-known designer and author Steve Krug, who in the famous book Don't Make Me Think! states: "people often ask me: what is the most important thing I should do if I want to make sure my site or my app is easy to use? The answer is simple. Nothing important should never be more than two clicks away or not speak the user's language or be consistent. This is ... «Don't make me think! !»" [2] [Krug 20 I 4, p. 39]. The steps reported, from here forward, present, in an explanatory and synthetic way, some of the research and development activities conducted to follow up to an organic design of the new UID application.

\section{Existing analysis}

The development of the UID app began with the analysis and recognition of the areas and tools already in use on the official website of the Association. The goal was not to reproduce existing functionality but to implement and improve, where possible, the communication of events and activities usable by mobile devices. To proceed with the examination, the most common user flow diagrams (User Flow) were used to understand the structuring of the UID site and its internal development (Web-Tree). The analysis (fig. 7) already contains the first project proposals, many of which remained out from the app's current development and that could be resumed in the future by the Association. Among these, a system of awards for the most active and virtuous users and the creation of dynamic and interactive infographics for the consultation of data collected by the scientific community.

\section{The choice of Progressive Web App}

The Android and iOS versions of a mobile application have numerous differences in the user-side interface and interaction, traceable among the design guidelines of both operating systems. For the experimental nature of the project and to predict a gradual implementation, other modules and additional functions have chosen to adopt a progressive web app (PWA) over time. These are programmable websites in the HTML standard to simulate, in a responsive manner, the behavior of an app through simple access from browsers. The solution saves a mobile version of the device desktop that simulates the interaction that would be via native app in many respects, with the advantage of being accessible from any device and to be more easily updatable. 

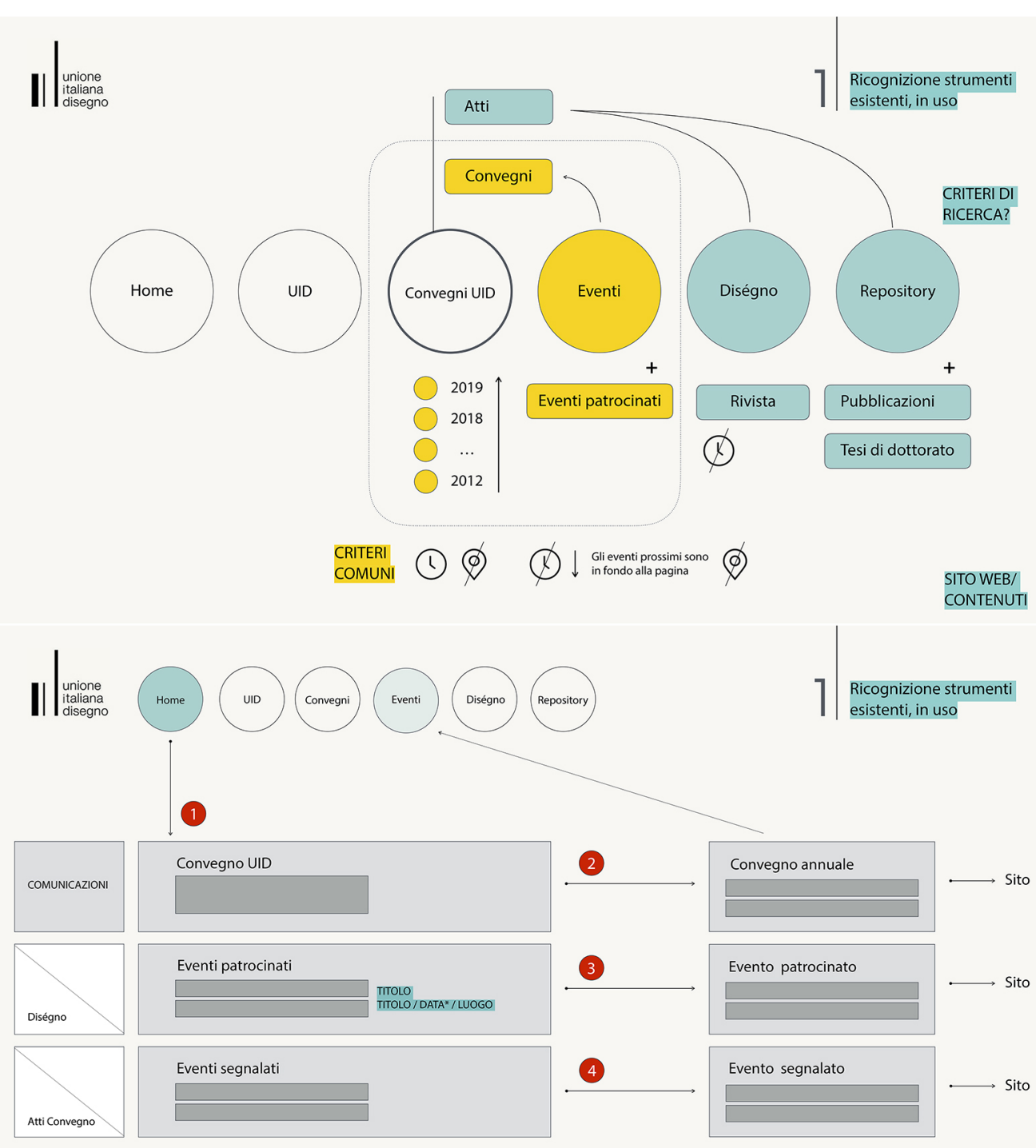

DATA*:

()!

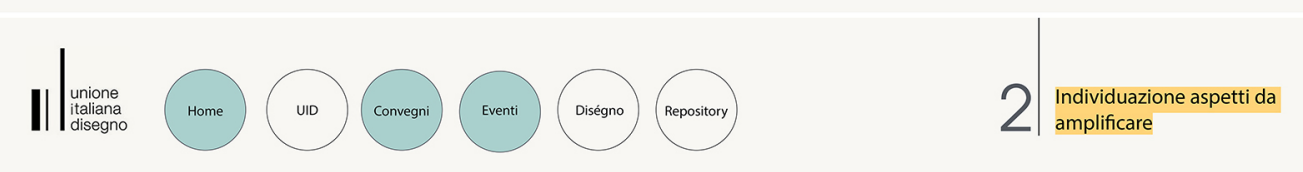


Fig. 8. Triadic color scheme used for relevant menus or links in reading the pages.

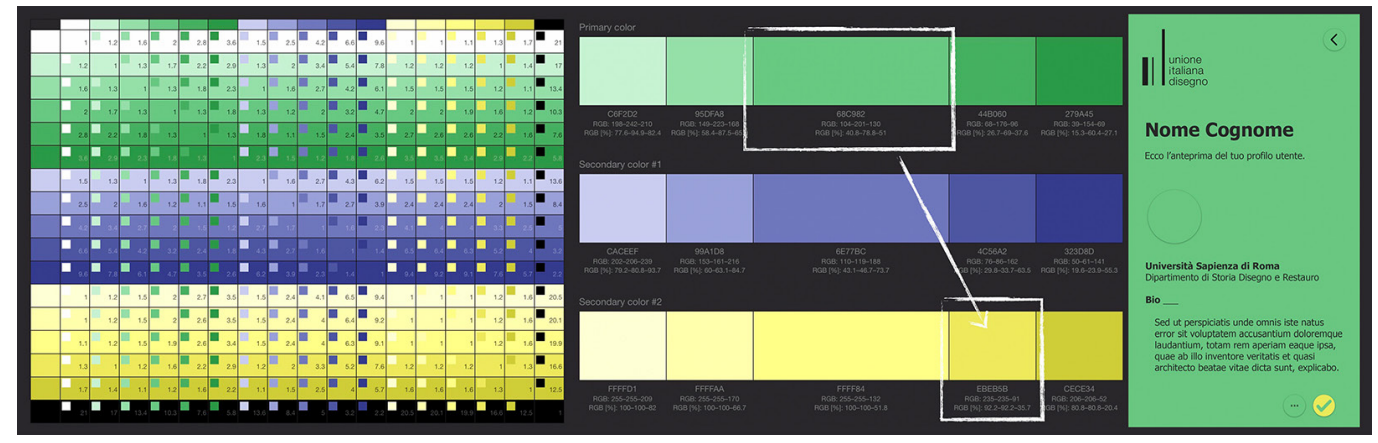

\section{User interface and color role in accessibility}

In the development of the application's user interface, particular attention was paid to the issue of accessibility, both in compliance with the European directives and in the customization of visual and chromatic content. Regarding compliance with the regulations [3], the graphical interface adopted allows all users -including those affected by forms of disability- access to information [4]. The appearance that most characterizes the graphic language adopted in the UID application concerns the use of color. The chromatic palette has taken a semantic role in recognizing the navigation map from the initial visual project. The three areas of knowing, communicating, and connecting were associated with three colors: green water, blue and yellow. Furthermore, the adoption of a triadic color scheme, maximizing the contrast, allowed to give attention to some relevant menus or links in reading the pages (fig. 8), while similar color schemes (fig. 9) have generated change in the chromatic gradation where a specific theme is investigated (as in the case of keywords). If the aspects described above are topical in the web design, the app proposes, in addition to the objective of canceling visual barriers, to inform users about the different modes of color perception and allows them to customize the user interface concerning every need. From the user profiling and creation screen (fig. IOa), you can reach the accessibility page (fig. IOb), in which the different modes of visual perception (fig. IOc) are indicated via a pop-up menu, comparing the normal vision with the most common forms of daltonism, namely protanopia, deuter-
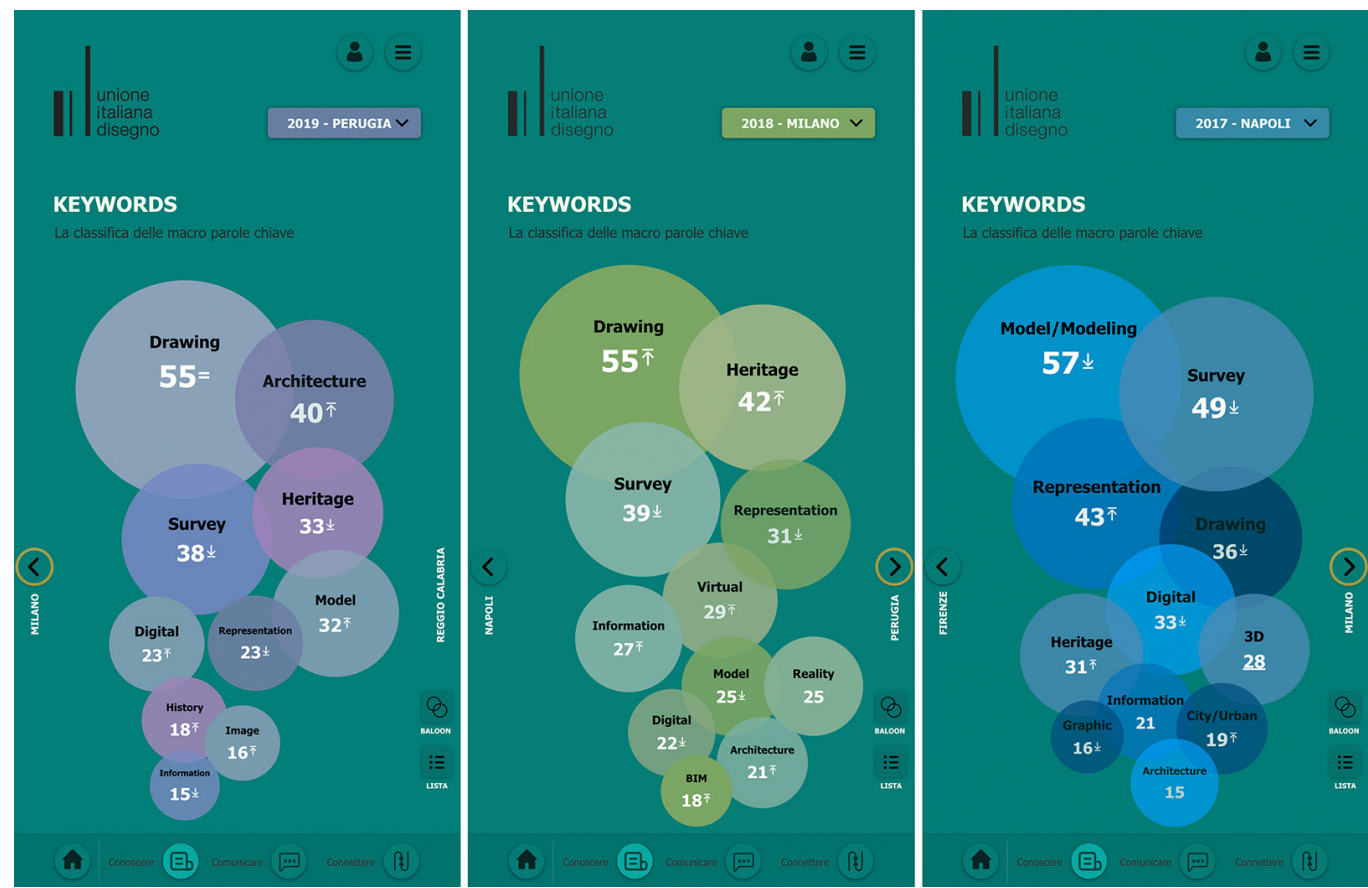
anopia, tritanopia and achromatopsia (fig. I0d). By choosing between the newly mentioned modes, the app can vary and replace the base colors in those that best adhere to the range of shades perceptible by the user (fig. I I), allowing more effective reading of the contents. The possible application configurations are multiple and look to a central theme for anyone who takes care of visual communication: the relativity of color and its wide perceptive range. In the first pages of the known Zur Farbenlehre (color theory) by Johann Wolfgang Goethe, the German narrator and playwright claimed that "the colors [...] completely belong to the subject and the eye" [Goethe 2014 , p. 2l], to specify that there are "physiological colors, since they belong to the healthy eye and since we consider them as the necessary conditions of seeing [...] and pathological colors, which make it possible to better understand than physiological ones, as well as any abnormal condition it makes possible to understand the normal condition" [Goethe 2014, p. 2 I]. In conclusion, the purpose of the graphic interface project, the subject of this brief discussion, was to consider the relativism of perception and, at the same time, to allow more concrete usability from users with vision disorders.

Fig. 10. User profiling and creation screen (a). In different modalities of visual perception (c) visted perception (c) are Compla a pop-up men Comparison between the normal vision and the most common form of daltonism, namely protanopia, deuteranopia tritanopia and achromatopsia (d)
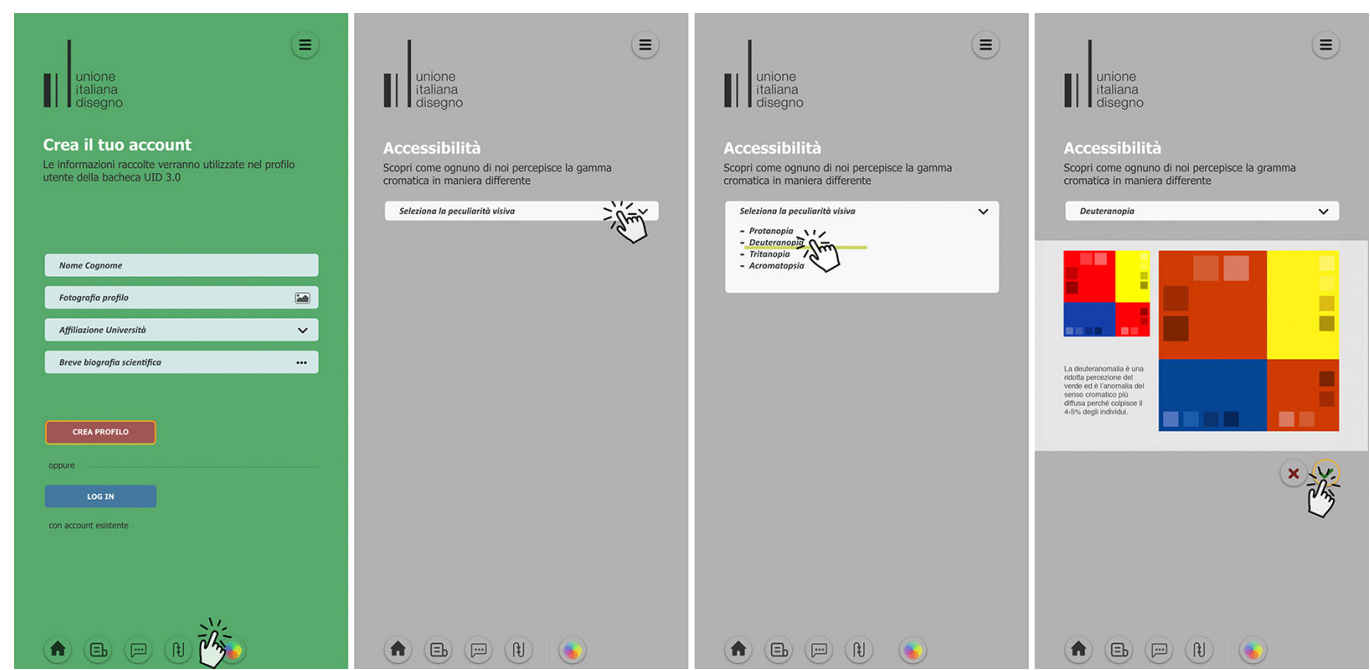

\section{Development scenarios}

As we have said, on the basis of the mockup and the animated prototype created and perfected following the discussion with the scientific community, the concrete development of the APP has begun, also thanks to the IT support provided by the project. The actual response of users to the functions currently implemented in the application will determine in the future the possibility of a its functional expansion, in directions that have emerged ex post. There are in fact some aspects which, although they cannot be developed at the same time as they would require greater temporal and substantial resources and higher skills, deserve particular attention in view of a future evolution. First of all, the possibility of starting further reflections on emerging research topics, which can be seen in the trend of newly acquired keywords, and which would have a lot to say about the different and heterogeneous directions towards which the disciplinary sector evolves spontaneously. It would also be interesting, for the same reason, to track the searches that users conduct by browsing the application, in order to highlight the prevailing and / or emerging scientific interests. Furthermore, the analysis and development of reward systems capable of encouraging the use of the future application, to amplify its potential in terms of knowledge, communication and connection, would be equally remarkable. 
Fig. I I. By choosing between different modalities of visual perception, the app can vary and replace the base colors in those that best adhere to the range of users' perceptible shades.
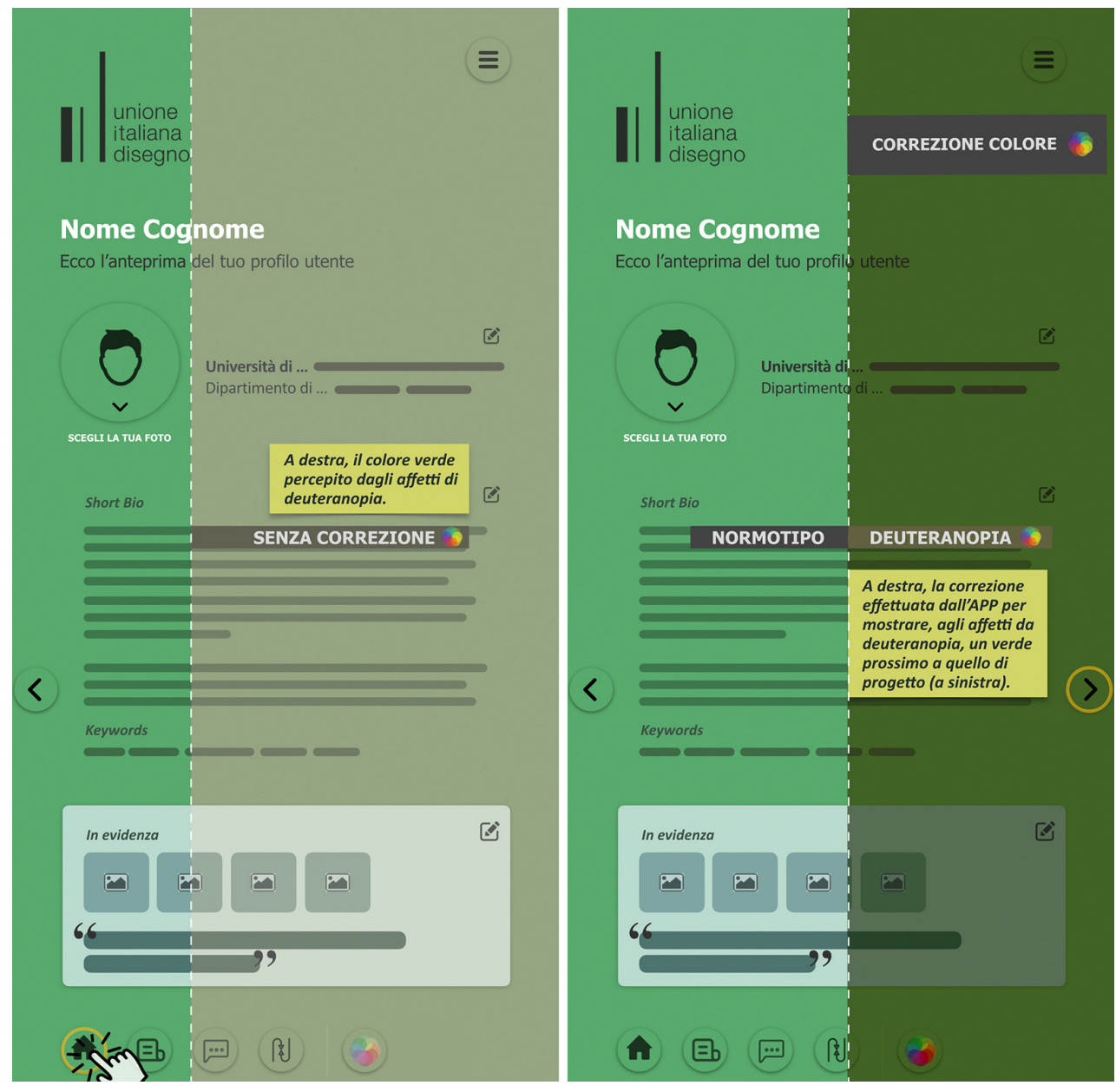

\section{Acknowledgements}

We thank the UID, and in particular, President Prof. Francesca Fatta, Prof. Giuseppe Amoruso, and the Commission of the UID 2.0-3.0 competition for the opportunity to implement the winning project described here. We thank Professors Salvatore Barba, Maurizio Bocconcono, Enrico Cicalò, Alessandra Ciraffi, Alessandro Luigini, Fabio Quici, Graziano Mario Valenti for scientific advice and Dr. Paolo Burzacca for the consulting in the design and testing phases of the prototype. We thank the colleagues Sofia Menconero, Anna dell'Amico, and Matteo Flavio Mancini for documental support in the prototype user-profiles simulation.

\section{Credits}

The authors worked on the whole project in every phase. Raissa Garozzo, Martino Pavignano, and Jessica Romor -to which scientific coordination was assigned-- have dealt with collecting, selecting, normalizing, and analyzing data. Cristian Farinella and Lorena Greco have developed the user interface design, wireframe, mockup, and animated prototype. For attribution, the authors wrote the paragraphs as follows: I and 8 Jessica Romor, 2 Raissa Garozzo, 3 Martino Pavignano, 4-6 Cristian Farinella, 7 Lorena Greco.

\section{Notes}

[I]The animation of the application prototype can be reached at the address < https://bit.ly/2GhfA9o> (accessed 2021, May 25).

[2] Steve Krug. Don't Make Me Think, Revisited: A Common Sense Approach to Web Usability. Apple Books, p. 39.

[3] We refer in particular to the Decreto Legislativo of I 0 Agosto 20 I 8, n. I 06, available at <https://www.gazzettaufficiale.it/eli/ $\mathrm{id} / 2018 / 09 / \mathrm{l}$ I/ $18 \mathrm{G} 00133 / \mathrm{sg}>$ (accessed 202 I, May 25). This is the decree of adaptation to European legislation, in terms of accessibility of websites and mobile applications of public bodies.

[4] Here are some examples. The interactions on active links, via finger touch, involve large areas, so as to ensure users with mobility difficulties in the use of their hands can access the functions on the screen without difficulty. The sounds used emphasize the graphic animations but are always supported by confirmation menus accessible through sight, without compromising the experience of use in the presence of hearing disorders or deafness. Finally, any type of flashing or stroboscopic light effect was avoided, to avoid the possible incidence of epileptic seizures. 


\section{References}

Goethe J.W. (20|4). Teoria del colore. Milano: II Saggiatore.

Krug S. (20 I4). Don't Make Me Think, Revisited:A Common Sense Approach to Web Usability. Indianapolis (USA): New Riders (3 edizione).

Luigini A. (2020). Ricerca interdisciplinare e ICAR I7: una proposta per la definizione di un modello condiviso. In: Arena A. et al. (a cura di). Connettere: un disegno per annodare e tessere. Atti del $42^{\circ}$ Convegno Internazionale dei Docenti delle Discipline della Rappresentazione. Milano: Franco Angeli, pp. 567-575.

Shafique M. (2013). Thinking inside the box? Intellectual structure of the knowledge base of innovation research (1988-2008). In Strategic Management Journal, 34(I), pp. 62-93.

Yang S. et al. (2016). Visualizing the intellectual structure of information science (2006-20I5): Introducing author keyword coupling analysis. In Journal of Informetrics, IO(I), pp. I32-150.

\section{Authors}

Cristian Farinella, Sapienza Università di Roma, cristian.farinella@uniromal.it

Raissa Garozzo, Università degli Studi di Catania, raissa.garozzo@unict.it

Lorena Greco, Sapienza Università di Roma, lorena.greco@uniromal.it

Martino Pavignano, Politecnico di Torino, martino.pavignano@polito.it

Jessica Romor, Sapienza Università di Roma, jessica.romor@uniromal .it

To cite this chapter. Farinella Cristian, Garozzo Raissa, Greco Lorena, Pavignano Martino, Romor Jessica (2021). Connettere per conoscere e comunicare: sviluppi dell'applicazione UID 3.0/Connecting to know and communicate: development of the UID 3.0 application. In Arena A., Arena M., Mediati D., Raffa P. (a cura di). Connettere. Un disegno per annodare e tessere. Linguaggi Distanze Tecnologie. Atti del $42^{\circ}$ Convegno Internazionale dei Docenti delle Discipline della Rappresentazione/Connecting. Drawing for weaving relationship. Languages Distances Technologies. Proceedings of the $42^{\text {th }}$ International Conference of Representation Disciplines Teachers. Milano: FrancoAngeli, pp. 700-721. 